\title{
REVIEW
}

\section{Application of biotechnological tools to Quercus improvement}

\author{
Ana M. Vieitez $\cdot$ Elena Corredoira $\cdot$ M. Teresa Martinez $\cdot$ M. Carmen San-Jose $\cdot$ Conchi \\ Sanchez · Silvia Valladares $\cdot$ Nieves Vidal $\cdot$ Antonio Ballester ${ }^{*}$ \\ Instituto de Investigaciones Agrobiológicas de Galicia, CSIC, Avda. de Vigo s/n, Campus Sur, \\ Apartado 122, 15780 Santiago de Compostela, Spain \\ *Corresponding author (aballester@iiag.csic.es)
}

\begin{abstract}
The genus Quercus, which belongs to the family Fagaceae, is native to the northern hemisphere and includes deciduous and evergreen species. The trees of the different species are very important from both economic and ecological perspectives. Application of new technological approaches (which span the fields of plant developmental biology, genetic transformation, conservation of elite germplasm and discovery of genes associated with complex multigenic traits) to these long-rotation hardwoods may be of interest for accelerating tree improvement programs. This review provides a summary of the advances made in the application of biotechnological tools to specific oak species. Significant progress has been made in the area of clonal propagation via organogenesis and somatic embryogenesis (SE). Standardized procedures have been developed for micropropagating the most important European (Q. robur, Q. petarea, Q. suber) and American (Q. alba, Q. bicolor, Q. rubra) oaks by axillary shoot growth. Although regenerated plantlets are grown in experimental trials, large scale propagation of oak species has not been carried out.

The induction of SE in oaks from juvenile explants is generally not problematic, although the use of explants other than zygotic embryos is much less efficient. During the last decade, enormous advances have been made in inducing SE from selected adult trees, mainly specimens of pedunculate oak (Q. robur) and cork oak (Q. suber). Advances in the understanding of the maturation and germination steps are required for better use of embryogenic process in clonal forestry.
\end{abstract}

Quercus species are late-maturing and late-flowering, exhibit irregular seed set, and produce seeds that are recalcitrant to storage by conventional procedures. Vitrification-based cryopreservation techniques were used successfully in somatic embryos of pedunculate oak and cork oak and an applied genbank of cork oak selected genotypes is now under development. The feasibility of genetic transformation of pedunculate oak and cork oak somatic embryos by means of co-culture techniques with several strains of Agrobacterium tumefaciens has also been demonstrated. 
To date, most research on the genomics of Quercus species has concerned population genetics. Approaches using functional genomics to examine the molecular and cellular mechanisms that control organogenesis and or somatic embryogenesis are still scarce and efforts on the isolation and characterization of genes related to other specific traits should be intensified in the near future, as this would help improve the practical application of clonal forestry in recalcitrant species such as oaks.

Keywords Cryopreservation $\cdot$ genetic transformation $\cdot$ genomics $\cdot$ in vitro tissue culture $\cdot$ micropropagation $\cdot$ oak $\cdot$ somatic embryogenesis $\cdot$ tree improvement

\section{Introduction}

Breeding of long-rotation hardwoods remains less well developed than that of short-rotation species (poplars, eucalyptus, willows) and has always lagged behind that of conifers. Investment in projects with an expected lifetime of over 40 years, such as those on long-rotation hardwood species, has never been attractive. Quercus species are included in the group of long-rotation hardwoods for which no long-term tree improvement programs have been carried out in either Europe or in North America (Savill and Kanowski 1993; Steiner 1993; Savill et al. 2005).

Conventional tree breeding programs comprises several steps, including: i) provenance trials and or stands of natural origin as the initial phase, ii) seed stand establishment, iii) phenotypic selection of plus trees that may be grafted and planted in clone banks, iv) progeny trials and production of seed orchards for identification of individuals with good genotypes and high combinatory ability, and v) vegetative propagation. Species of the genus Quercus, such as Quercus robur (pedunculate oak) and Q. petraea (sessile oak), usually reach seed-bearing age at between 40 and 100 years old, and the mast seed crops vary according to the individual tree, population region and year (Ducousso and Bordacs 2004), and they are likely to produce good seed crops once every 3-5 years. In addition, vegetative propagation is of extremely limited success because it is very difficult to root cuttings of most tree species (including several Quercus species) if they are taken from selected mature trees. Grafting is the method of choice for oak vegetative propagation, but delayed compatibility in Quercus has been observed. Expression of graft incompatibility can be delayed up to 7 years and symptoms include significant scion overgrowth of the rootstock, vigorous suckering, and precocious flowering (Coggeshall 1996). According to these limitations in conventional tree breeding approaches, the question remains as to whether biotechnology would be practically useful in the genetic improvement of long-rotation hardwoods and, more specifically, Quercus species. Molecular 
genetic techniques are undergoing rapid development and may be able to be applied in oak breeding programs, and in physiological and taxonomic studies, as marker traits in selection, identification of individual genotypes, certification of seed orchard products, gene mapping, identification of genes or alleles associated with traits of economic significance (wood properties), etc. (Burley and Kanowski 2005; Grattapaglia et al. 2009). Theoretically, transgenic trees may constitute an important tool for speeding up breeding cycles for traits determined in juvenile woody plants (Flachowski et al. 2009), increasing disease resistance (Fenning 2006), improving wood quality and tree form (Häggman et al. 2006; Grattapaglia et al. 2009), etc. However, there is considerable controversy about the use of genetically modified trees in plantations, so that their use may be restricted in the short- to medium-term future (Bradford et al. 2005; Brunner et al. 2007; Gartland and Oliver 2007; Sederoff 2007; Strauss et al. 2009).

Several recent reviews have described the possibilities of forest biotechnology as an emerging opportunity in relation to tree improvement (Fenning and Gershenzon 2002); some of these reviews cover both coniferous and hardwood species (Nehra et al. 2005) or only hardwoods (Merkle and Nairn 2005; Pijut et al. 2007), but none are devoted specifically to species of the genus Quercus. In this review article, we discuss methods that may provide the basis for accelerated improvement of several oak species through biotechnology. Topics addressed in this review include the micropropagation of mature selected material through axillary shoot development, the potential of somatic embryogenesis in light of the most recent results, advances in germplasm conservation through cryopreservation, state-of-the-art in the genetic transformation of the species and the molecular and genomics-related efforts made with the aim of improving these species.

\section{The genus Quercus}

The genus Quercus, which belongs to the family Fagaceae, is native to the northern hemisphere and includes deciduous and evergreen species extending from cold latitudes to tropical Asia and the Americas. Its taxonomic classification is very difficult as the genus could be represented by 200 (Neger and Münch 1950), 320 (Krahl-Urban 1959), or 450 species (Krüssmann 1978). The differences in these numbers are partly explained by the definition of interspecific hybrids as separate species and the sub-division of ecological forms into species (Kleinschmit 1993). Frequent hybridization has produced large population of hybrids and high levels of introgression have led to different species in populations sharing up to $50 \%$ of their genetic information (Conte et al. 2007; Gömöry and Schmidtová 2007). The genus is subdivided into two subgenera: Quercus and Cyclobalanopsis and the former is further divided into four sections: Protobalanus, Cerris, Quercus (white oaks) and Rubrae (red oaks) (Ducousso and Bordacs 2004). 
For the purpose of the present review, we will refer hereafter to the oak species with which most biotechnological approaches have been used.

Twenty-four oak species and hybrids are currently grown in Europe, among which pedunculate oak (Quercus robur) and sessile oak (Q. petraeae) -which belong to the white oak section- are the most widely distributed and are the most important oak species on the continent, from both economic and ecological perspectives. These oaks, which extend from Ireland to Sicily (Italy) and from the Ural mountains to central Norway (Repo et al. 2008) are large trees that reach $30-40 \mathrm{~m}$ in height and live for 800 years or more. The wood from both pedunculate and sessile oaks was used for ship construction and today is employed in furniture making and flooring, timber frame building, veneer production and to make barrels in which wine and spirits are aged. High forest, coppice-with-standards and coppice are the three main silvicultural regimes. Natural regeneration should be a priority but, as it is sometimes difficult, plantations with reproducible material of high genetic value are required (Ducousso and Bordacs 2004).

The European evergreen Quercus suber (cork oak) is one of the oak species most characteristic of the Mediterranean ecosystem, and plays important ecological, economic and social roles in parts of southern Portugal and Spain and northern Algeria and Morocco (Knapic et al. 2008) and other countries in the Mediterranean basin. Portugal produces more than half of the cork produced in the world (Catry et al. 2009). This valuable raw material is mainly used to produce wine stoppers (corks).

From the 58 tree-sized native species of oak in the USA, which cover an estimated area of $448,000 \mathrm{~km}^{2}$, Quercus rubra (red oak) and Q. alba (white oak) are the most important and widely distributed (Steiner 1993). Red oak, which is one of the fastest growing of the species, is distributed from northeastern USA reaching west to central Minnesota, eastern Nebraska and Kansas. The geographic range of white oak extends from Maine to Minnesota, south to eastern Texas and northern Florida. The wood of these American oaks is harvested for use in cabinet making, interior finishes, and general construction.

Oak decline syndrome affects oaks worldwide and is of great concern. Oak decline (also known as oak dieback or oak mortality) is an episodic and gradual phenomenon characterized by a general loss of vigor caused by complex interactions between different biotic and abiotic factors and which is not limited to any one species or species group (Wargo et al. 1983; Manion and Lachance 1992; Thomas et al. 2002; Repo et al. 2008). Trees are weakened by environmental stresses such as drought, waterlogging, frost, pests, etc. Oak decline occurs all over Europe and, in its current phase, has been going on since the beginning of the 1980s (Jung et al. 2000). Affected trees display progressive dieback from the tips of the branches, production of chlorotic foliage, and development of epicormic shoots on main branches and stem and 
premature autumn leaf colour. Tree mortality is variable and is related to the stand, geographic area, species, etc.

In addition to the episodic phenomenon of oak dieback, there are specific situations where mortality of oaks can only be explained by biotic factors. Fungal pathogens colonizing either the root system (Armillaria sp.) or the bole bark (Biscoyniauxia mediterranea) and bark insects such as Agrilus species have been reported as important opportunistic parasites, which are organisms unable to colonize a host unless it has been first weakened as a result of another stress (Marçais and Bréda 2006). The green oak leaf roller (Tortrix viridiana L.) is an oligophagus moth that only parasitizes members of the genus Quercus and leads to defoliation of oaks in spring (Schroeder and Degen 2008); oak powdery mildew caused by Erysiphe alphitoides (formerly Microsphaera alphitoides) is the most common disease in the susceptible pedunculate oak (Hajji et al. 2009); the lesions at root or collar level caused by Phytophthora sp. are well documented (Robin et al. 1992; Jung et al. 2000; Vettraino et al. 2002). Special mention should be made of sudden oak death, a fungal disease caused by Phytophthora ramorum, which has already killed tens of thousands of native coast live oak and tanoak trees in California (Meentemeyer et al. 2008; Brown and Allen-Diaz 2009). This fungus has also been identified in Europe, although the infective capacity of European oaks is, at present, much lower than that of American oaks (Forestry Commission 2009). Nevertheless, expansion of these diseases would increase in the future under predicted conditions of climate change, as expected with Phytophthora cinnamomi according to simulation models (Bergot et al. 2004).

\section{In vitro tissue culture}

\section{Micropropagation through axillary shoots}

Tissue culture techniques were initially applied to different oak species because they provide appropriate tools for rapid production of genotypes to regenerate trees with desired traits and to capture all the genetic superiority without involving any gene segregation. These techniques would, at least theoretically, alleviate the lack of acorn production of selected oak trees on a yearly basis, as well as difficulties in producing offspring with desired traits, difficulties in storing acorns and the low rooting capacity of stem cuttings.

The studies on micropropagation of the most intensively investigated and of the greatest economic importance oak species are summarized in Table 1 . The first attempts to micropropagate oak species were carried out, as in many other tree species, with zygotic embryos or seedlings as a source of explants for culture initiation. The disadvantage of using juvenile rather than adult specimens is clear, but was a necessary step to determine the response of oak explants to in vitro conditions. Early studies on the micropropagation of pedunculate and 
sessile oaks used embryonic axes as well as shoot apices and nodal segments isolated from 3-6month-old seedlings (Vieitez et al. 1985; San-José et al. 1990; Chalupa 1993). Although the composition of the mineral media was not decisive in initiating cultures, Woody Plant Medium (WPM) (Lloyd and McCown 1980) and Gresshoff and Doy (1972) medium (GD) were superior to other mineral media for shoot multiplication cultures. In an experiment carried out to identify the most suitable mineral medium in this step in cultures of pedunculate oak, Vieitez et al. (1985) found that, of the eight media tested, the best results were achieved with GD medium. The authors reported that the use of Murashige and Skoog (1962) (MS) medium promoted poorly developed axillary buds, small leaves, no basal callus formation and necrosis that spread from the shoot tips to the whole culture. Cultures grown on MS medium also developed thick, succulent or hyperhydric shoots. The superiority of GD medium was also demonstrated for sessile oak cultures (San-José et al. 1990). The most widely used plant regulator at the multiplication stage is 6-benzylaminopurine (BA) (used at different concentrations), although the effect of thidiazuron in stimulating shoot proliferation was also evaluated (Chalupa 1988). Shoot multiplication in oak cultures does not occur a rosette-like cluster, but by the production of a few, more-or-less elongated shoots. Elongation of shoots may be required prior to rooting. Elongation medium differs from multiplication medium only in that the concentration of BA was either reduced by a factor of ten or was replaced by zeatin (San-José et al. 1988). The addition of zeatin to the multiplication medium improved the proliferation of American oak shoot cultures (Vieitez et al. 1993, 2009).

In the rooting step, isolated shoots $(1.5-3 \mathrm{~cm})$ were placed in media containing indole-butyric acid (IBA) or naphthalene-acetic acid (NAA) for a period of 7 or 8 days, with later transfer to an auxin-free medium (Chalupa 1993; Juncker and Favre 1989; Vieitez et al. 1994; Puddephat et al. 1999). Dipping the basal ends of the shoots for 1-2 min in highly concentrated solutions of IBA (1 g/L) and transfer to an auxin-free medium was also carried out (San-José et al. 1988). However, after many experiments, it was found that the best rooting efficiency was achieved by culturing the shoots in media containing $122.5 \mu \mathrm{M}$ IBA for $24 \mathrm{~h}$, with subsequent transfer to auxin-free media containing $1 \%$ activated charcoal. For all genotypes tested, the charcoal benefited both shoot quality and root system development, and the latter was enhanced by the formation of many lateral roots (Sánchez et al. 1996; Vieitez et al. 2009). In addition, ex vitro rooting experiments were also performed with pedunculate oak microcuttings, which were treated with commercial rooting powder, inserted in peat-perlite substrate and placed under plastic tunnels in a greenhouse (Meier-Dinkel et al. 1993).

While seedling explants are relatively easy to micropropagate, explants from mature trees tend to lose their regeneration potential. When cloning mature trees, it is important to first determine which part of the individual contains the most responsive cells, as some parts of trees 
are morphogenetically more competent than others. In hardwood trees and a few gymnosperms, responsive tissues are found at the root-shoot junction, in root or stump sprouts, sphaeroblasts, and epicormic shoots (Bonga et al. 2008, 2010). In vitro plants of pedunculate, sessile, cork and red oaks were regenerated using stump sprouts or epicormic shoots from mature trees, following the above described protocols (Chalupa 1993; Vieitez et al. 1985, 1993, 1994; Favre and Juncker 1987; San-José et al. 1988, 1990; Romano et al., 1992; Evers et al. 1993; Sánchez et al. 1996). These results appear to indicate the good potential for the application of micropropagation techniques in oak forestry. However, several concerns, which may limit application of the technology at a commercial scale, have been identified. The most serious limitations concern: i) the effect of the genotype, ii) the progressive decline of shoot proliferation during successive subcultures and iii) difficulties in propagating mature selected trees lacking stump sprouts or epicormic shoots.

The effect of the genotype on culture initiation and proliferation, which is a common phenomenon in many species, was studied by Meier-Dinkel et al. (1993), who established in vitro cultures from germinated acorns harvested from 11 grafted selected pedunculate oak trees growing in two stands. After 8 months, shoot productivity varied between ten and more than 1000 shoots/genotype; rooting and survival were strongly dependent on the genotype, with values ranging between $10 \%$ and $80 \%$ for individual genotypes. Furthermore, clonal effects in propagating oak trees were also studied by Juncker and Favre (1989) in pedunculate oak, and data from 16 genotypes derived from seedlings were compared by using principal component and hierarchical cluster analyses. This study confirmed that the between-genotype differences in oak micropropagation are large enough to explain the lack of repeatability in culture establishment, subculture and rooting. No significant between-provenance differences were observed, while the within-provenance differences were high.

The decline in the proliferation capacity of vertically placed oak cultures after several subcultures is a common bottleneck mentioned in most of the publications on the subject. This phenomenon not only affects European oaks but, more specifically, American oaks. All attempts to micropropagate white oak (Q. alba) or swamp white oak (Q. bicolor) have been unsuccessful. Shoot cultures initiated from terminal and lateral buds of white oak seedlings died through gradual loss of vigor (Schwarz and Schlarbaum 1993). Shoot tip necrosis, dormancy and decline of shoot growth are common problems described as affecting micropropagation of red oak from juvenile seedling material (Vengadesan and Pijut 2007). According to McCown (2000), the decreased capacity for proliferation may be as a result of the episodic growth exhibited by Quercus, as the growth is not continuous. The difficulties associated with in vitro culture of oak may be attributed to the inability to achieve uniform and continuous shoot growth. To address the problem, a procedure initially applied to pedunculate oak (San-José et al. 
1988; Vieitez et al. 1994) and red oak cultures (Vieitez et al. 1993; Sánchez et al. 1996) was used. Briefly, shoot explants from which the apices $(2 \mathrm{~mm})$ have been removed were placed horizontally on the medium and transferred onto fresh medium after 2 weeks, during the 4-week multiplication cycle. After this period, all new shoots longer than $10 \mathrm{~mm}$ were harvested and used for multiplication or rooting, and the donor shoots were recultured (transferred to fresh medium) to produce a new crop. The procedure was repeated 3 or 4 times in all (Ballester et al. 2009). By use of this procedure, healthy cultures were produced from pedunculate oak and also from red oak. When the shoots of the American white oaks Q. alba and Q. bicolor were cultured in the conventional upright position for 4-6 weeks, the strong episodic character of the shoots was shown, with arrested shoot growth generally followed by death of explants. However, culture of the explants in a horizontal position and subsequent reculture of the original explant led, for the first time, to production of vigorous plants of selected American oaks (Vieitez et al. 2009). To explain the beneficial effect of this method in obtaining vigorous shoots, it should be considered that horizontal culture is a form of mechanical stress that may favor synthesis of ethylene in the culture vessel (Anten et al. 2006). It is also possible that horizontal cultures may differ from vertical cultures in both the distribution and transport of endogenous growth regulators and the supply of nutrients.

As mentioned above, oak plantlets have been generated in vitro from explants derived from basal shoots or stump sprouts of mature trees, although it was difficult to establish in vitro cultures from buds of the current season's growth in the crown (Sánchez 1991). In the absence of mature material with juvenile physiological characteristics, such as stump sprouts or epicormic shoots, rejuvenation or reinvigoration procedures could be applied to mature trees (Ballester et al. 1990). Mature reactive material may be obtained using hedging and stool bed methods, which make it possible to use preformed dormant buds that remain quiescent after early initiation. Outgrowth of dormant buds often leads to the development of physiologically juvenile shoots, not only those located in the lower part of the trunk but also those arising higher up in the tree. Sectioning the trunk of a mature tree to induce epicormic shoots was used as a method of rejuvenation (Evers et al. 1993). However, a variant of this technique (without destroying the tree), consisting of sectioning thick crown branches $(3-5 \mathrm{~cm})$ to induce the flushing epicormic shoots, was also used (Vieitez et al. 1994, 2009; Ballester et al. 2009). Briefly, crown branches collected between December and March, cut into 25-30 cm segments, are placed on moist perlite beds in a growth chamber, in order to induce new shoots. The flushed shoots, which develop 10-15 days after severance, are used as source of explants, which develop into shoots exhibiting vigorous growth, long internodes and leaves resembling a more juvenile looking (less lobed) type. After excision of these shoots from the original explants, they may be cultured using the previously described horizontal culture method, and the in vitro 
multiplication rates recorded were similar to those of cultures of juvenile origin. Following this procedure, genotypes of oak trees older than 300 years have been successfully established in vitro (Vieitez et al. 1994).

After more than 25 years of work on the micropropagation of different oak species through axillary shoot culture, it is possible to conclude the feasibility of the regeneration of whole plants. Interesting technological advances have been carried out that allow oak plants to grow in the field. Plant regeneration by axillary branching is often effective, even with adult material, but it is not sufficiently efficient to be applied on commercial scale. This is in contrast with other genera within the Fagaceae family, such as European chestnut, in which large scale micropropagation was reported (Vieitez et al. 2007). Alternative in vitro propagation methods, such as somatic embryogenesis, should be explored.

\section{Somatic embryogenesis}

Somatic embryogenesis (SE) is a powerful tool for improvement of forest trees as is considered to be the most appropriate means of in vitro regeneration of woody plants. Large-scale propagation of selected material, genetic transformation, and cryopreservation of elite genotypes are among the most immediate applications of SE. Furthermore, SE may be the only method of regenerating truly juvenile propagules of difficult-to-propagate species. In oaks, induction of the embryogenic process from juvenile explants is generally not problematic, although induction with explants other than mature or immature zygotic embryos is much less efficient. Studies on somatic embryogenesis in different species of the genus Quercus, mostly induced from juvenile material, have been summarized in different reviews (Chalupa 1995; Manzanera et al. 1996; Wilhelm 2000), but even since the last date, further progress has been reported in different oak species (Table 2).

Somatic embryo induction According to the definition of recalcitrance in clonal propagation given by Bonga et al. (2010), the most important Quercus species belongs to recalcitrant species. The selection of the most reactive explant isolated at the appropriate time applies not only for the propagation through axillary shoot development, but also when the clonal propagation is through SE. As stated in the preceding section, reactive material retaining a certain level of juvenile characters is found in root and stump sprouts, sphaeroblasts, and epicormic shoots of mature oak trees. In the specific case of SE induction, another area of interest involves tissues close to cells that are involved in the sexual process, in which the timing of explant isolation and the application of mild stress are extremely important aspects to be considered. 
Expanding leaves excised from epicormic shoots forced to sprout in crown branch segments, according to the methodology previously defined for the micropropagation of mature oak trees via axillary branching (Vieitez et al. 1994), were used as initial explants for the induction of SE in mature oak trees. Following this procedure, the first report on induction of SE in explants of mature Q. suber trees was made by Hernández et al. (2001), who initiated cultures from leaves of epicormic shoots, whereas Pinto et al. (2002) also obtained embryogenic calluses in leaves from flushed cuttings of a 60-year-old cork oak tree. Further experiments were carried out for better definition of the induction of SE in cork oak, giving rise to consistent embryogenic systems for the propagation of several hundred-year-old trees (Hernández et al. 2003a). These authors reported that the induction step in leaf explants was performed by successive culture of initial explants in three culture media differing in the concentration of plant growth regulators (PGR): the primary induction medium supplemented with $10 \mu \mathrm{M}$ BA plus $50 \mu \mathrm{M}$ NAA, the secondary medium in which the concentration of PGR was reduced to $0.5 \mu \mathrm{M}$ BA and $0.5 \mu \mathrm{M}$ NAA, and the expression medium, which is devoid of PGR; the combined application of NAA and BA in primary medium was essential for induction (Hernández et al. 2003a; Toribio et al. 2005). Genotype and time of harvesting, as well as their interaction, significantly influenced the frequency of embryogenic induction, which ranged between 8\% and 91\% (Hernández et al. 2003b).

Following a similar procedure, SE was also achieved in expanding leaves excised from newly sprouted epicormic shoots forced from branch segments of mature Q. robur trees (Toribio et al. 2004). Initiation of somatic embryos was achieved by a multi-stage treatment procedure based on the culture scheme reported for seedling leaf explants of Q. robur (Cuenca et al. 1999). The explants were successively cultured in: 1) induction medium (M1) based on MS basal medium and supplemented with $5 \mathrm{mg} / \mathrm{l}$ casein hydrolysate, $2.2 \mu \mathrm{M}$ BA and $21.5 \mu \mathrm{M}$ NAA, applied in darkness at $25^{\circ} \mathrm{C}$ for 6-8 weeks; 2) a second medium (M2) of the same composition as the induction medium except that BA and NAA were reduced to respectively 0.44 and $0.54 \mu \mathrm{M}$, with culture continued for 4 weeks under a $16 \mathrm{~h}$ photoperiod, and 3) expression medium (M3) with the same components but without PGR. The explants were maintained on this medium for 8-10 weeks, for a total 20 weeks after the start of culture. Induction of somatic embryos was correlated with the asymmetric distribution of auxin in the tissues, which appears to be necessary for de novo initiation of organ primordia under culture conditions (Zhao et al. 2008). Accordingly, the next steps in the process were the transfer of oak explants to media with decreasing amounts of PGR, or without PGR, and culture under photoperiodic conditions. Seven out of 30 trees tested showed embryogenic response but at lower frequencies (0.3\% to 3.6\%) than those obtained with adult $Q$. suber trees; the collection date also influenced the embryogenic response (Toribio et al. 2004; Valladares et al. 2006). The 
scheme applied to SE of Q. robur differed from that used for Q. suber (Hernández et al. 2003a) in that the culture media were based on MS mineral components and a lower concentration of PGR in the induction media, whereas Schenk and Hildebrandt (1972) macronutrients and higher concentrations of both BA $(10 \mu \mathrm{M})$ and NAA $(50 \mu \mathrm{M})$ were successful for leaves from adult cork oak.

Once it was confirmed that genotype and selection of responsive explants collected at the optimal time were successful criteria for embryogenic induction in mature oak trees, other alternatives were proposed for searching for totipotent cells or tissues in recalcitrant species. Culture of the shoot apical meristems may provide a solution to problems related to recalcitrance, although the survival rates were normally very low (Bonga et al. 2010). Successful induction of somatic embryos in pedunculate oak, based on the use of shoot apex explants from material derived from adult trees has recently been reported (San-José et al. 2010). In the latter study, induction of embryogenic cultures was achieved in shoot tip explants (2 mm long, comprising the apical meristem and 3-4 pairs of leaf primordia) and leaf explants (the two apical- most expanding leaves) excised from axillary shoot cultures of three out of the five $Q$. robur trees over 100 years old that were evaluated. Within each responsive genotype, both leaf and shoot tip explants produced embryogenic responses, and embryogenic frequencies were relatively low (1.7\%-12\%) for both explant types, as occurred in the case of leaf explants excised from forced epicormic shoots of mature trees. Interesting, the failure to induce SE from shoot tips isolated from forced epicormic shoots of the corresponding trees suggest that the sterilization process has a negative effect on this type of explant. The use of shoot multiplication cultures to initiate the embryogenic process offers advantages over the use of explants from forced epicormic shoots from field-grown trees, as it ensures the availability of plant material all around the year and avoids the need to sterilize the plant tissues (San-José et al. 2010). The impact of genotype appears to be one of the limiting factors for the induction step of the SE process, as documented for other Quercus species (Hernández et al. 2003b; Vengadesan and Pijut 2009). Given that the frequencies of SE obtained in leaf explants from mature trees were not very different from those achieved using leaf explants from seedlings (Cuenca et al. 1999), the juvenile condition of the source tree, at least in leaf tissue, does not appear to be as crucial a factor as the genotype. A similar embryogenic response was observed between leaves from cork oak seedlings and from adult trees, as a result of the use of presumably reinvigorated or rejuvenated condition of the epicormic shoots (Hernández et al. 2003a).

With regard to the suitability of floral tissues for initiating SE, the study of Bueno et al. (1997), in which microspore-derived embryos of cork oak were obtained by combining a sucrose starvation treatment with a mild heat shock at $33^{\circ} \mathrm{C}$ for 5 days followed by culture at $25^{\circ} \mathrm{C}$ in a medium lacking PGR, is worthy of mention. After only 20 days of culture, embryos 
were observed growing from the interior of the anthers, breaking free from the degenerating anther walls. These results indicate that stress may be the major signal for inhibition of gametophytic development of the microspores in favor of the embryogenic pathway. Ploidy level analysis, carried out on long-term (up to 12 months) microspore-derived embryo cultures, showed that most of the embryos (90.7\%) were haploid, corresponding to their microspore origin, although a low percentage (7.3\%) of diploid embryos was also observed (Bueno et al. 2003). These results confirm the accepted assumption that morphological changes observed in stressed microspores appear to be a prerequisite for transition to the de-differentiated state required for embryogenic induction (Bonga et al. 2010). Furthermore, a remarkable difference with respect to the induction of SE from leaf explants of the same species (Hernández et al. 2003a) must be highlighted, as no PGR were required to induce the androgenic process, and embryos were developed in shorter periods of time.

Although most of the studies carried out during the last decade refer to $Q$. suber and $Q$. robur, a few have involved the induction of somatic embryogenesis in holm oak (Q. ilex) (Mauri and Manzanera 2003) and red oak (Q. rubra) (Vengadesan and Pijut 2009). In both species, immature zygotic embryos were used as explants, giving rise to an induction frequency of $4.3 \%$ in the former, whereas a higher response (66\%) of embryogenic callus was recorded in the latter. In addition, the induction of SE in Q. alba (white oak) following a procedure similar to that defined for pedunculate oak (San-José et al. 2010) was recently demonstrated (unpublished). Shoot tip explants and leaf explants excised from shoot cultures derived from selected 5-year-old trees produced somatic embryos at higher frequencies (up to 47\%) than those reported for $Q$. robur. Interestingly, significant differences between explant types were observed, with a higher embryogenic response produced in the first expanding leaf from the apex.

There is evidence that soluble signal molecules may control cell differentiation in plant SE and that conditioned culture media from embryogenic cultures can promote SE. Signal molecules such as extracellular proteins (endochitinases), arabinogalactan proteins (AGPs) and lipochitooligosaccharides (LCOs) have been found to be important for the development of the embryogenic process (von Arnold et al. 2002). The effect of different concentrations of AGPs from both larch wood (Ben Amar et al. 2007) and gum arabic (Letarte et al. 2006) on initiation of somatic embryos in Q. robur and Q. alba was tested. Preliminary results indicate that the addition of these components to the culture media enhances the embryogenic response in both species.

Somatic embryo development in original explants When leaf explants or shoot apex explants derived from mature $Q$. robur trees were cultured in induction medium M1, they initially 
responded by developing callus tissue at frequencies depending on the genotype. Callus proliferation was observed within two weeks and was mainly differentiated on the petiole stump region of leaf explants or cut surface of shoot tip explants, then progressing towards the distal ends. The SE followed an indirect pathway from this callus tissue formed in the original explants. In contrast, no callus formation was reported to occur in cork oak leaves where somatic embryos appeared almost directly at the leaf surface, without a defined pattern of arrangement (Hernández et al. 2003a). The timing of somatic embryo development was also influenced by genotype; some somatic embryos first began to appear towards the end of culture on M2 medium (9-10 weeks after culture initiation), although most emerged during culture in M3 expression medium, whereas in other genotypes, embryos began to become evident following transfer of the explants to M3 medium (12-15 weeks after culture initiation). Embryogenic cultures consisted of creamy-translucent nodular structures and somatic embryos, which developed from the callus tissue in both types of explant; induction of embryogenic tissues appears to require dissociation and partial necrosis of the specific callus regions. The embryogenic nodular structures observed in Q. robur were probably similar to the translucent nodules observed in other Quercus species, including Q. ilex (Féraud-Keller and Espagnac 1989) and Q. suber (El Mâataoui et al. 1990), or to the nodular proembryogenic masses described in other related species such as chestnut (Carraway and Merkle 1997; Corredoira et al. 2006a). In Q. alba, nodular embryogenic structures also originated from the callus tissue developed on the abaxial surface of leaf explants, and arose faster than those reported in pedunculate oak and cork oak, as the first embryogenic structures were evident during culture in M1 induction medium (6-8 weeks of culture initiation). Embryogenic nodular structures were embryogenic in character as they originated from embryogenic cell aggregates and in turn generated somatic embryos or other nodular structures as a form of repetitive embryogenesis.

Anatomical study Research on embryogenic cell initiation and early developmental stages of primary embryos induced in leaf explants (Corredoira et al. 2006b) and shoot tip explants (SanJosé et al. 2010) confirmed an indirect SE process. During culture in M1 induction medium, explants yielded callus tissue comprising parenchymatic cells with vascular elements, and actively dividing meristematic cells produced superficial layers of callus protuberances; these meristematic zones generally evolved into differentiated parenchyma cells rather than somatic embryos. At the end of culture in M2 medium and during culture in M3 medium, certain cells acquired an embryogenic character; these cells appeared interspersed with parenchyma cells, which were undergoing further vacuolization and degradation, in superficial callus regions. The formation of embryogenic cells was also associated with extensive division of perivascular cells in differentiating vascular bundles in the callus. In white oak, the formation of embryogenic 
cells appears to be associated with a felodermis-like meristem or diffuse cambium established in superficial layers of the callus; in this case, cells exhibiting embryogenic-like cytological features also displayed intense accumulation of phenolic substances. Phenol accumulation in cells surrounding somatic embryos has been reported in myrtle (Canhoto et al. 1999) and may play an unknown role during early stages of SE in eucalyptus (Pinto et al. 2008). It is possible that this may account for the physical or physiological isolation of potential embryogenic cells as one of the pre-requisites for triggering the embryogenic program. Successive division of the embryogenic cells led to the formation of a few-celled proembryos and embryogenic aggregates within a thick common cell wall, indicating a probable unicellular origin, although a multicellular origin from bulging embryogenic areas cannot be discounted. Embryogenic aggregates gave rise to well-formed somatic embryos or to embryogenic nodular structures, which were formed from small vacuolated cells and meristematic areas, but lacked clear bipolarity. These cells were able to produce somatic embryos of multicellular origin from their meristematic areas, and somatic embryos of unicellular origin from embryogenic cells shed from the outermost layers. Somatic embryos, including cotyledonary stage embryos with shoot and root meristems, were apparent at successive stages of development.

Overall, these results suggest that leaf tissues are suitable explants for initiating SE in mature trees in different Quercus species, although pedunculate oak appears to be more recalcitrant than cork oak and white oak and the results obtained with the former closely resemble those obtained in leaf explants of a 50-year-old Q. ilex tree (Féraud-Keller and Espagnac 1989). Even in the case of shoot tip explants, the apical meristem itself generally senesced and died during culture, and the basal leaf primordia attached to the axial zone were the real source of generating calluses and, subsequently, embryogenic tissues. This suggests that the production of somatic embryos from oak shoot tip explants may be considered as a particular case of SE in which leaf primordia and their axillary basal meristems were involved. This is especially evident in Q. alba, where basal leaf primordia included in the shoot tip explants were the source of somatic embryos produced by this type of explant.

Secondary embryogenesis Once embryo initiation was achieved, even though induction frequencies were low, a large number of somatic embryos can be obtained by secondary embryogenesis (Toribio et al. 2004; Valladares et al. 2006). After isolation of somatic embryos from the original explant and culture in proliferation media, a recurrent embryogenesis mechanism is triggered, thus enabling the formation of secondary embryos giving rise to clonal embryogenic lines. Secondary embryos were mainly formed on the hypocotyl or root zone of the primary embryo, although some also appeared on the cotyledons. Production for scaling up and long-term maintenance of SE in different species of Quercus depends on their embryogenic 
capacity through secondary embryogenesis. A semisolid proliferation medium supplemented with either a low concentration of cytokinins and auxins, or media without PGR were used for multiplication of embryogenic lines derived from pedunculate oak (Cuenca et al. 1999; Wilhelm 2000) and cork oak (Hernández et al. 2003b). For embryogenic lines derived from mature $Q$. robur trees, a proliferation medium consisting of MS basal medium including $500 \mathrm{mg} / \mathrm{l}$ casein hydrolysate, $0.44 \mu \mathrm{M}$ BA and $0.27 \mu \mathrm{M}$ NAA was initially adopted, and has made possible the continuous supply of somatic embryos during several years (Valladares et al. 2006; Sánchez et al. 2008). Further optimization experiments demonstrated that PGR treatment significantly affected proliferation and quality of the embryos (Mallón et al. 2011) with the best rates achieved when the proliferation medium was supplemented with $0.44 \mu \mathrm{M}$ BA alone, resulting in significantly higher total numbers of embryos and of cotyledonary-stage embryos (used for germination purposes). Embryo production was affected by genotype, as expected given the impact of genotype on the induction step and germination step of the oak embryogenic systems. A genotypic effect was also documented in the proliferation of embryogenic lines of $Q$. suber, based on significant differences in the relative increase in fresh weight and number of ‘detachable’ embryos (Hernández et al. 2003b).

The histological origin and structural organization of the secondary embryogenesis process were investigated in $Q$. robur and $Q$. suber. A multicellular origin of embryos, and both direct and indirect secondary embryogenesis responses were reported in Q. robur (Zezgouti et al. 2001). In the case of the cork oak system (maintained in PGR-free medium), secondary embryos arose either in a multicellular budding pathway from a compact mass of proliferation or from isolated single cells (unicellular origin) in friable callus induced with relatively high levels of 2,4-D (Puigdejarrols et al. 1996, 2001).

Maturation, germination and plantlet conversion As in many other woody species, the low rate of conversion into plantlets is a major limitation for large-scale application of oak somatic embryogenesis. Maturation has been hampered in many species by repetitive embryogenesis, immaturity, embryo dormancy and precocious germination. During the maturation stage, somatic embryos should accumulate specific storage products at the appropriate time, as occurs in zygotic embryos (von Arnold et al. 2002). Abscisic acid (ABA) plays a fundamental role in processes such as regulation of the synthesis of storage proteins and late embryogenesisabundant (LEA) proteins and water-stress-induced gene expression (Dodeman et al. 1997), in the reduction of secondary embryogenesis and in the inhibition of precocious germination (Kernode 1995). Desiccation, at least in zygotic embryos, is known to play a role in switching from the embryogenic to the germination phase. Reduction of intra- and intercellular-water 
content by means of osmotic stress of the culture media may promote healthy development by mimicking the natural course of zygotic embryogenesis (Compton and Gray 1996).

Several approaches have been carried out to improve germination (root growth) and plantlet conversion (root and shoot growth) of somatic embryos in different oak species. Although the germination response, in terms of root development, may achieve values up to $80 \%$ in various oak species, many of the germinating embryos only exhibited root development, and the conversion rates were still not satisfactory (3\% to 32\%, Sánchez et al. 2003). A maturation stage allowing synthesis and accumulation of storage compounds and acquisition of desiccation tolerance probably also has to be completed by oak somatic embryos prior to germination. One form of inducing partial desiccation is to use an appropriate concentration and type of carbohydrate in the culture medium in order to induce osmotic stress. The culture of somatic embryos, prior to germination, in maturation media supplemented with $6 \%$ sorbitol or $6 \%$ manitol plus 2-3\% sucrose for one month, significantly favored the conversion rates in Q. robur embryogenic lines derived from leaf explants of seedlings (Sánchez et al. 2003), and in lines derived from mature trees (Valladares et al. 2006). These authors have also demonstrated that germination and conversion ability greatly depended on genotype; after 8 weeks of culture in germination medium, embryos of one genotype failed to germinate, and they continued to produce large numbers of secondary embryos while other genotypes exhibited conversion rates of up to $70 \%$ (Valladares et al. 2006). However, García-Martín et al. (2001) pointed out that the somatic embryo response of $Q$. suber was not improved by using a high concentration of sucrose prior to germination, unless accompanied by two months of chilling. Osmotic stress induced by increasing the concentration of agar (1\%) in the maturation medium, with subsequent partial desiccation (moisture loss of 20-25\%) promoted maturation and subsequent germination of pedunculate oak somatic embryos of culture lines of zygotic origin, thus achieving conversion rates up to 63\% (Sunderlikova and Wilhelm 2002; Prewein et al. 2004). These authors also pointed out that a progressive increase in the concentration of proline and a $50 \%$ decrease in the concentration of ABA were observed to occur during embryo maturation (Prewein et al. 2004). There are no conclusive results on the exogenous application of ABA to promote maturation and subsequent germination of oak embryos. Although the addition of ABA to the culture media significantly reduced unwanted recurrent embryogenesis in Q. ilex (Mauri and Manzanera 2004) and significantly stimulated somatic embryo maturation in Q. suber (García-Martín et al. 2005), the treatments carried out in cork oak (Toribio et al. 2005) and in pedunculate oak did not have significant effects on germination and plantlet conversion.

For a number of woody species, culture of somatic embryos in a maturation medium must be followed by a period of cold storage to break embryo dormancy, a process associated with changes in the endogenous levels of ABA and gibberellic acid, $\left(\mathrm{GA}_{3}\right)$ (Deng and Cornu 1992). 
The application of a 2-month cold period as a pre-germination treatment stimulated embryo germination and conversion in material from Q. suber of immature zygote origin (FernándezGuijarro et al. 1995; García-Martín et al. 2001; Gonzalez-Benito et al. 2002a) and Q. ilex (Mauri and Manzanera 2004), as well as in embryogenic lines from Q. suber of mature tree origin (Hernández et al. 2003b). Similarly, the application of activated charcoal and a mixture of glutamine, arginine and asparagine coupled with cold storage at $4^{\circ} \mathrm{C}$ for two months had a favorable effect on plantlet conversion in cork oak (Pintos et al. 2010). In the embryogenic system derived from immature cotyledons of $Q$. rubra, germination was performed by desiccation for 3 days followed by cold storage for 8 weeks (Vengadesan and Pijut 2009). However, two months of storage at $4^{\circ} \mathrm{C}$ between maturation and germination treatments did not have any significant effect on the conversion frequency in pedunculate oak embryos from mature trees, although germination, in terms of root-only development, was promoted in the three embryogenic lines investigated (Martínez et al. 2008). Overall, stratification appears to be an important treatment for promoting germination in oak somatic embryos, as occurred in chestnut, another recalcitrant seed species and member of the family Fagaceae (Corredoira et al. 2003; Andrade and Merkle 2005).

Mature somatic embryos of $Q$. robur were usually germinated in media supplemented with 0.28-0.56 $\mu \mathrm{M}$ BA with or without IBA $(0.1 \mu \mathrm{M})$ (Cuenca et al. 1999; Sunderlikova and Wilhelm 2002; Valladares et al. 2006), whereas germination media devoid of PGR were used with Q. suber (Hernández et al. 2003b) and Q. ilex (Mauri and Manzanera 2004). A positive effect of inclusion of $\mathrm{GA}_{3}$ in the germination medium was reported for $Q$. acutissima somatic embryos (Kim 2000), which is consistent with the results obtained by Vengadesan and Pijut (2009) in Q. rubra somatic embryos, in which the combination of BA $(0.44 \mu \mathrm{M})$ and $\mathrm{GA}_{3}(0.29$ $\mu \mathrm{M})$ favored simultaneous development of both the shoot and the root, thus yielding a high frequency of germination (61\%). However, preculture of $Q$. robur somatic embryos in $\mathrm{GA}_{3}$ $(8.65 \mu \mathrm{M})$ medium for two weeks prior to transfer to germination medium did not improve the conversion rates, but did reduce root length and the number of leaves per regenerated plantlet (Sánchez et al. 2003).

Epicotyl and shoot development in oak germinating embryos appears to be a limiting factor, and plantlet conversion is still not operational on a large scale. The shoot promoting ability of thidiazuron (TDZ) suggests that this may influence the organization and development of what would otherwise be a poorly developed shoot apical meristem, and the effect of this compound was therefore investigated during the germination step in Q. robur (Martínez et al. 2008). Addition of 0.05-0.1 $\mu \mathrm{M}$ TDZ to the germination medium for an initial period of seven days induced multiple shoot formation in the epicotyl region (the main shoot plus cotyledonary axillary shoots) of the germinating embryos, increasing the plantlet conversion frequency and 
the shoot-only elongation frequency, especially in the case of hard-to-convert embryogenic lines. Shoots excised from shoot-only germinating embryos can be elongated, multiplied and rooted by proven micropropagation procedures via axillary shoot proliferation (Martínez et al. 2008), as already described in this review. This procedure would also provide an interesting tool to study if rejuvenation of the regenerated shoots through somatic embryogenesis (induced from mature tissues) occurs. The combined strategy based on somatic embryo conversion to the extent that it is possible, and proliferation and rooting the shoots of unconverted embryos that produce them, has been proposed for production of plants from embryogenic transgenic lines of European chestnut and American chestnut (Maynard et al. 2008). The initial experiments involving application of TDZ to germinating embryos also gave rise to an additional finding that adventitious bud regeneration was induced on the cotyledons of TDZ-treated embryos (Martínez et al. 2008), which may be useful in genetic transformation procedures applied to this species.

In an attempt to understand the maturation and germination processes in pedunculate oak, the expression patterns of the storage protein legumin gene and Em- and dehydrin-like homologues were investigated (Sunderlikova and Wilhelm 2002; Sunderlikova et al 2009a). The latter authors concluded that these proteins may be useful as markers of the physiological and maturation condition of somatic embryos (see also Genomics section).

Data from field experiments with plants derived from somatic embryos are scarce and limited to $Q$. suber plants regenerated from mature selected trees, from their half-sib progenies by somatic embryogenesis and from zygotic seedlings of the same families. Differences as a result of genotype and family effects were notable and no apparent morphological alterations were detected among the trees of tested progenies (Celestino et al. 2007).

\section{Genetic stability}

The genetic stability of in vitro regenerated plants is an essential requisite for large-scale clonal forestry. Evaluation of genetic fidelity in plantlets of the genus Quercus obtained through somatic embryogenesis is of vital importance because in these species, as a result of their long life cycle, assessment and detection of possible somaclonal variation is critical to prevent the spread of instability among high-value genotypes. PCR-based markers (RAPDs, AFLPs, SSRs) and cytological studies have been used to evaluate the potential genetic variation in embryogenic cultures and regenerated plants of different Quercus species.

Four embryogenic lines initiated from explants of 4-week-old Quercus robur seedlings maintained for more than 4 years by secondary embryogenesis were subjected to RAPD analysis. In addition to these lines, a line derived from a nodular embryogenic callus, which ceased to be embryogenic after a few subculture cycles, was also analyzed (Sánchez et al. 
2003). No polymorphism was detected within and between embryogenic lines originated from different types of explant from the same seedling, but enough polymorphism was detected among genotypes originating from different plants to enable the origins to be distinguished. There were also no differences in DNA sequences between regenerated plantlets and their somatic embryos of origin. However, these authors observed genetic variation between the callus line that had lost its embryogenic capacity and the three embryogenic lines derived from the same seedling (Sánchez et al. 2003). The genomic alteration appears to have caused loss of the capacity for embryogenesis. Callus proliferation probably involves fewer active genes than the formation of somatic embryos or converted plantlets, and mutations in these active genes may be the cause of the loss of ability to undergo secondary embryogenesis (Heinze and Schmidt, 1994). De Verno et al. (1994) suggested that the embryogenic tissue may be composed of a mixture of altered and unaltered cells and genomes, and that only the unaltered genome would be able to regenerate plantlets. In addition, five microsatellite loci were used to test the genetic stability of three somatic embryogenic lines derived from immature zygotic embryos of Q. robur and derived plantlets (Wilhelm et al. 2005). Variation in DNA was detected among somatic embryos within the three embryogenic lines with a high mutation frequency of 29.2$62.5 \%$, depending on the genotype, whereas no genetic instability was found among the regenerated plantlets. The authors, in line with the results reported by Sánchez et al. (2003), suggested that regeneration would be a selective process in which conversion into plants would be prevented in somatic embryos with mutations. Both RAPD and AFLP markers were used to record differences between embryogenic lines, even between those that arose from half-sib zygotic embryos, but no genetic variation was found among somatic embryos within embryogenic lines of zygotic embryo origin of Q. suber (Gallego et al. 1997; Hornero et al. 2001).

The genetic stability of in vitro cultures and regenerated plants compared with the original selected material from which they are derived is essential for the maintenance and propagation of elite genotypes. RAPD analysis was used to check the genetic stability of somatic embryos induced from mature $Q$. robur tissues. No evidence of genetic changes was found within or between those embryogenic lines and the mature trees of origin, and stability was also maintained between the regenerated plantlets and trees of origin (Valladares et al., 2006). However, pre-existing variation among tissues from the donor plant was attributed to DNA instability detected among AFLPs in $Q$. suber somatic embryos induced from leaves of adult trees (Hornero et al. 2001). Similarly, Lopes et al. (2006) used microsatellites to demonstrate mutations in $Q$. suber somatic embryos derived from leaves from a mature field tree. Nevertheless these authors found no somaclonal variation in another embryogenic line of adult origin. 
Therefore, to certify the genetic stability of regenerated plants by in vitro culture, it is important to use a variety of approaches such as flow cytometry, since PCR-based markers fail to detect variation at the ploidy level. Endemann et al. (2001) used flow cytometry analysis to detect tetraploidy in $8 \%$ of pedunculate oak somatic embryos originated from zygotic embryos and maintained by secondary embryogenesis, and the changes in chromosome number appeared to be correlated with the duration of the in vitro culture. Using the same technique, Loureiro et al. (2005) found no polyploidy or significant variations in DNA content among cork oak somatic embryos, and between the embryos and the mature mother trees. These authors also observed the same ploidy level when the somatic embryos were germinated and converted to plantlets.

Pre-existing variation in the original explants, probably linked to the genotype, and de novo induced mutational events during the embryogenic process, appear to be the most important aspects related to the genetic stability of oak somatic embryos (Wilhelm et al. 2005).

\section{Cryopreservation}

Gene conservation programmes are recommended for oak species because the genetic resources are threatened by multiple factors such as the introduction of exotic genotypes, species purification, neglected practices, diseases, etc. In situ conservation methods are generally preferred, although if natural methods are not sufficient, ex situ conservation through clonal seed orchards should be used (Ducousso and Bordacs 2004). Furthermore, as pointed out in the Introduction section, Quercus species are late-maturing and late-flowering, exhibit irregular seed set, and produce seeds that are recalcitrant to conventional conservation procedures. Recalcitrant seeds have a high water content and can be only stored for relatively short periods of time because they are sensitive to desiccation.

There are several potential advantages of using synthetic seeds, including the potential for long-term storage and for automation and commercialization purposes, but there is scant information on the feasibility of encapsulation in Quercus species. In one study, apical buds of $Q$. robur and $Q$. cerris were encapsulated in an alginate matrix, giving rise to successful regeneration after 6 weeks of cold storage at $4^{\circ} \mathrm{C}$ (Tsvetkov and Hausman 2005). Furthermore, the production of synthetic seeds and their ability to be stored has been investigated in somatic embryos of Q. robur (Prewein and Wilhelm 2003) and Q. suber (Pintos et al. 2008). However, the results obtained in both studies showed that conversion rates were considerably reduced after 2-3-months of cold storage at $4^{\circ} \mathrm{C}$, and only short-term storage of encapsulated embryos was possible. 
In general, strategies for forest biodiversity conservation are today well-defined (Häggman et al. 2008), among which cryopreservation is viewed as a complementary, secondary storage method designed as a secure backup for living collections (Reed 2008). Well-defined in vitro techniques are required to recover the multiplication capacity of supercooled material via axillary shoot growth or somatic embryogenesis. Only under these conditions, the application of cryopreservation in the development of large gene banks is justified. Cryopreservation is currently routinely applied to embryogenic lines awaiting field testing results (Sutton 2002) and the first approaches on the application of cryopreservation to hardwood forest tree species have recently been published (Harvengt et al. 2004; Vidal et al. 2010a).

Zygotic embryo axes of pedunculate oak have been cryopreserved using the simplest desiccation-based method, by means of fat flash drying and direct immersion in liquid nitrogen (LN), which yielded appreciable germination recovery rates (Berjak et al. 2000). These rates were not improved when more complex dehydration procedures were applied. Better results were reported with embryonic axes of Quercus faginea, a tree that occurs widely in the Iberian peninsula (González-Benito and Pérez-Ruiz 1992). Prior to storage in LN, the axes were desiccated either under sterile conditions in a laminar air flow bench for different periods of time, or by soaking them in 15\% dimethylsulfoxide (DMSO) for $1 \mathrm{~h}$ and subsequently immersing them in LN. The best recovery rates (60\% germination) were obtained after desiccation for $3 \mathrm{~h}$, after which the moisture content decreased from the initial value of $63.7 \%$ to $12 \%$. However, attempts to subject cork oak zygotic embryo axes to cryostorage by partial desiccation followed by rapid immersion in LN were unsuccessful, as only unorganized postcooled growth of axes was reported (González-Benito et al. 2002b).

As progress in the induction of somatic embryogenesis from selected trees has been evident in the last years in species such as pendunculate and cork oak, interest in the cryopreservation of embryogenic lines has increased. Cryopreservation techniques referred to as 'vitrification-based techniques' are now applied to different oak species. Briefly, embryo clumps (4-6 mg) of globular or heart-shaped secondary embryos isolated from embryogenic lines were pre-cultured for 3 days on a solid MS medium containing $0.3 \mathrm{M}$ sucrose, and were then transferred to fresh medium containing $0.7 \mathrm{M}$ sucrose for another 4 days. The embryos were placed in cryovials, then subjected to vitrification by application of PVS2 solution (30\% w/v glycerol, $15 \% \mathrm{w} / \mathrm{v}$ DMSO and 15\% w/v ethylenglycol in MS medium containing $0.4 \mathrm{M}$ sucrose) for $30 \mathrm{~min}$ at $25^{\circ} \mathrm{C}$, resuspension in the PVS2 solution and then plunging in LN. After rewarming, recovery rates (relative to the generation of new embryos from surviving cells of the cryopreserved clumps by repetitive embryogenesis) of $75 \%-80 \%$ were recorded for somatic embryos of pedunculate oak (Martínez et al. 2003; Sánchez et al 2008). Following a similar procedure, higher recovery rates (>90\%) were achieved with different embryogenic lines initiated from 
mature selected trees of cork oak (Valladares et al. 2004). Preculture on a medium containing sugars appeared to be an essential step for successful cryostorage in the vitrification procedure. A high concentration of sucrose may increase tolerance to desiccation, which may stimulate the accumulation of certain sugars in the cells. The effect of increased sugar content on cell integrity may cause a decrease in cell volume as a result of osmotic process and direct stabilization of membranes (Percy et al. 2001).

Construction of a large gene bank of cork oak genotypes by use of the cryopreservation methodology developed at laboratory level is a reality. Currently, $100 \%$ of the 51 embryogenic lines corresponding to genotypes of both juvenile (44 genotypes) and mature (7 genotypes) origins incorporated to the gene bank recovered their capacity to proliferate after immersion in LN. Furthermore, three experimental plots have been established with the selected materials to determine their productivity and heritable characters by investigation of progenies. During field testing, copies of the material will be preserved under LN (Vidal et al. 2010a).

One concern related to cryopreservation methods is the genetic stability of the post-cooled and regenerated plants. The potential somaclonal variation of in vitro tissue cultures, as well as the mutagenic potential of the most popular cryoprotectant component of the PVS2 vitrification solution, DMSO, are well-known, although to date there is no evidence of morphological or genetic alterations in forest trees as a result of cryopreservation (Häggman et al. 2008). Aronen et al. (1999) reported genetic changes in DMSO-treated, non-supercooled samples, but not in DMSO-treated and cryostored samples of Abies cephalonica somatic embryos during cryopreservation. The authors speculated that, although cryostorage does not remove the mutagenic potential of DMSO, it probably eliminates a high proportion of the cells bearing genetic changes. In our experience, RAPD profiles of 5 embryogenic lines of Quercus robur cryopreserved for years, and the corresponding regenerated plantlets were identical to those of the controls and no genetic instability (sporadic mutations or genetic reordering) was detected (Sánchez et al. 2008).

\section{Genetic transformation}

As pointed out above, the induction and proliferation of somatic embryos derived from both juvenile and mature material of different Quercus species has been demonstrated. Factors affecting the germination and conversion of somatic embryos into plantlets were also studied and, consequently, the most appropriate target material for the application of gene transfer is now available.

Genetic transformation protocols for cork oak embryogenic lines induced from both mature (Alvarez et al. 2004) and juvenile (Sánchez et al. 2005) materials through co-culture with different strains of Agrobacterium tumefaciens harbouring plasmids containing marker genes 
have been defined. An optimized protocol for Agrobacterium-mediated transformation of mature embryogenic masses of this species, in which variables such as the genotype, explant type and the preculture period were studied, has also been reported (Alvarez and Ordás 2007). Genotype has a strong influence on the transformation frequency, as only 3 out of the 6 embryogenic lines tested were kanamycin-resistant after 4 months of culture in selective media. The transformation efficiencies were highly variable among experiments, which may be related to the physiological state of the somatic embryo clumps used in the experiments. Unfortunately, the plantlet conversion rates were not reported in any of these studies. In addition, cork oak embryogenic masses were transformed using Agrobacterium strain AGL1, which carried the plasmid pBINUbiBar, harbouring the genes nptII and bar, the latter under control of the maize ubiquitin promoter. Varying activities of phosphinothricin acetyl transferase were detected among the lines, which carried 1-4 copies of the insert. The stability and expression of the transgenes 3 months after thawing of the cryopreserved transgenic embryogenic lines were confirmed by molecular and biochemical probes. Herbicide resistance has only been tested at laboratory level, as plantlet conversion has not been reported (Alvarez et al 2009).

Initial attempts to obtain transformed plants of pedunculate oak (Q. robur) were unsuccessful (Roest et al. 1991; Wilhelm et al. 1996). A protocol for genetic transformation of somatic embryos derived from juvenile (2 lines) and mature (3 lines) pedunculate oak trees co-cultured with the Agrobacterium strain EHA105 harbouring a p35SGUSINT plasmid containing a nptII marker gene and a uidA reporter gene, has recently been reported (Vidal et al. 2010b). Histochemical and molecular analyses confirmed the presence of nptII and uidA genes in the roots and leaves of transformed plants. Transformation efficiencies ranged from up to $2 \%$, in an embryogenic line derived from a 300-year-old tree, to $6 \%$ in a juvenile genotype. Twelve independent transgenic lines were obtained and transgenic plantlets were recovered and are growing in a greenhouse.

The feasibility of genetic transformation of pedunculate oak and cork oak somatic embryos by means of the co-culture technique with several Agrobacterium strains has been demonstrated. Taking into consideration these advances, the next step should be to study the response of these or other oak species after genetic transformation with genes of interest, as carried out with chestnut (Maynard et al. 2008), a member of the family Fagaceae.

\section{Genomics}

Genomic information on many forestry species has increased dramatically in recent years and genomic resources available for tree improvement and domestication programs include genomic sequencing, EST sequencing, transcript profiling, gene transfer, molecular markers for mapping and breeding, etc. (Merkle and Nairn 2005). With advances in molecular biology and 
identification of adaptive genes, differences in gene sequences for genes involved in the control of a particular adaptive trait would be used for assessing diversity and adaptiveness (Savill et al. 2005). Current progress in tree genomics is so rapid that few studies have been published to date and much documentation is often limited to electronic resources. There are a number of websites related to genomics and gene discovery in trees (Nehra et al. 2005). An integrated web-based resource for members of the Fagaceae family, including Quercus (Fagaceae Genomic Database (FGD) http:/www.fagaceae.org), has been developed. This site disseminates data and analyses by providing relevant sequence information, homology results, genetic/physical map information, SSrs, SNPs; and other genomic data are being posted as they become available. The most important information from studies involving the genomics of Quercus species, including construction of genetic linkage maps, microsatellite markers, ESTderived markers, transcriptome investigations and differential gene expression for the identification of genes involved in the adaptation of oak trees and QTL detection for phenotypic traits that respond to natural selection and to specific stresses, has been reviewed in detail (Kremer et al. 2007).

Most research activities involving the molecular genetics of Quercus have addressed population genetics, unlike in other forest species, for which tree improvement has been the main goal. Two oak mapping initiatives have been carried out: for European white oaks the objective is to detect QTLs that control morphological and adaptive traits involved in species differentiation (Petit et al. 2004; Saintagne et al. 2004; Scotti-Saintagne et al. 2004a), while in American red oaks, the ultimate goal is the detection of QTLs and genes that control heartwood color and resistance to specific pests (Aldrich et al. 2002).

Implementation studies have been carried out on transcriptomic investigations and differential gene expression to identify genes involved in the adaptation of oak species to their environments. Genetic variation of bud burst and early growth has been estimated in a full-sib family of Q. robur comprising 278 offsprings. Bud burst appears to be controlled by several QTLs with rather low to moderate effects and height growth depends on fewer QTLs with moderate to strong effects (Scotti-Saintagne et al. 2004b). After this, 801 ESTs were generated derived from 6 developmental stages of bud burst. Microarray and real-time RT-PCR showed that several differential expressions between quiescent and swelling buds constitute relevant candidates for the signaling pathway of bud burst in trees (Deroy et al. 2006).

Forest trees are threatened by changing environmental conditions because global climate change. Thirteen osmotic stress-induced genes of Quercus ssp. were included in genetic linkage maps of oak (Porth et al. 2005) and later studies on QTLs of tolerance to waterlogging in pedunculate oak identified significant clusters of QTLs, at inter- and intra-trait level, suggesting the occurrence of a genetically controlled cascade response to waterlogging (Parelle et al. 2007). 
Quantitative trait loci controlling water use efficiency and related traits were also studied in $Q$. robur (Brendel et al. 2008).

Vegetative propagation using either conventional cutting procedures and micropropagation techniques, are used for the deployment of improved genetic forest tree species. Assessment of rooting in cuttings of pedunculate oak allowed the detection of 10 QTLs explaining between 4\% and $13.8 \%$ of the phenotypic variance, of which the strongest were stable across years (ScottiSaintagne et al. 2005). Furthermore, a full-length cDNA clone named QrCPE, which is differentially expressed during in vitro culture of mature (difficult-to-root) and juvenile (easyto-root) shoots of pedunculate oak was identified by differential display (Gil et al. 2003). The deduced amino acid sequence showed that QrCPE encodes a small putative cell wall protein that is rich in glycine and histidine residues. Accumulation of QrCPE mRNA was higher in mature than in juvenile microshoots at the end of the multiplication and rooting steps. QrCPE accumulates in ontogenetically older organs of oak trees, although it is present in zygotic and somatic embryos but absent from callus cells. Expression of QrCPE gene was also investigated in juvenile-like microshoots during the in vitro rooting process, after demonstration of the auxin-mediated induction of this gene in rooting competent shoots (Covelo et al. 2009). On the other hand, an Em-like gene, QrEm, has been isolated from Q. robur zygotic embryos, which is expressed in the mid-maturation phase. Abundant transcript accumulation was observed when somatic embryos of the species were subjected to $6 \%$ sorbitol or after partial desiccation. The results of in situ hybridization experiments appear to suggest that the QrEm gene is embryospecific and its expression is developmentally regulated (Sunderlikova et al. 2009a). Furthermore, three dehydrin genes, QrDhn1, QrDhn2, QrDhn3, were isolated from pedunculate oak. The QrDhn1 gene was expressed during later stages of zygotic embryo development but only in somatic embryos when exposed to osmotic or desiccation stress. The other two dehydrin genes were expressed only in somatic embryos (both untreated and osmotically stressed), and the authors suggest that different dehydrins were involved in the process of seed maturation and response to altered osmotic (water status) conditions in somatic embryos (Sunderlikova et al. 2009b). These and other members of the dehydrin gene family may contribute to clarifying nonorthodox (oak) seed behavior and to identifying mechanisms related to desiccation tolerance. Finally, 17 differentially proteins have been identified in a proteomic study of $Q$. suber somatic and gametic in vitro culture-derived embryos. Some of the proteins identified are involved in stress and pollen development and others are associated with metabolism of tannins and phenylpropanoids (Gómez et al. 2009). Approaches using functional genomics to examine the molecular and cellular mechanisms that control organogenesis and somatic embryogenesis will contribute to better practical application of these processes to recalcitrant species such as oaks. 
From the development of genetic maps in species of Quercus, Castanea and Fagus (all genera belonging to the family Fagaceae) carried out to date, it appears obvious that molecular markers could be easily transferred from Quercus to Castanea (Barreneche et al. 2004; Casasoli et al. 2006), but less easily to Fagus, and ongoing activities in comparative mapping suggest that there is a strong macrosyntheny between the phylogenetically close genera Quercus and Castanea (Kremer et al. 2007).

\section{Conclusions}

Conventional long-term tree improvement programs have not been carried out in the longrotation species of the genus Quercus. The rapid development of biotechnological techniques, including in vitro tissue culture, gene transfer, conservation, molecular genetics associated with physiological and taxonomic studies, gene mapping, and identification of genes and alleles linked to specific traits, provides an opportunity for breeding, propagation, deployment and management applied to Quercus species. Although most of these species are classified as recalcitrant to regeneration through in vitro tissue culture, enormous progress has been made in the application of biotechnological tools to the most important species of Quercus during the last decade. Procedures of micropropagation through organogenesis and somatic embryogenesis using explants isolated from selected adult trees, and protocols for genetic transformation and cryopreservation of elite genotypes have been defined, allowing the regeneration of whole plants, regardless of the method used. However, the organogenic/embryogenic response is clearly dependent on the genotype and, in the embryogenic process, the low conversion rates of the somatic embryos into plantlets of most of the species/genotypes studied may be considered as one of the most important obstacles to the large scale propagation of selected oak genotypes. Most research involving genomics of Quercus species have concerned population genetics. Approaches using functional genomics to examine the molecular and cellular mechanisms that control organogenesis and or somatic embryogenesis are still scarce, and much effort should be made in this respect in the near future, to enable better application of oak clonal forestry. In addition, efforts should involve the isolation and characterization of genes related to other specific traits (i.e. disease and or pest resistance, wood quality, tree form), which would also be of interest for improving the species.

Acknowledgements This research was partly funded by the Xunta de Galicia (Spain) through project 09MRU002400PR. 


\section{References}

Aldrich PR, Michler C, Sun W, Romero-Severson J (2002) Microsatellite markers for northern red oak (Fagaceae: Quercus rubra). Mol Ecol Notes 2:472-475

Alvarez R, Alonso P, Cortizo M, Celestino C, Hernández I, Toribio T, Ordás RJ (2004). Genetic transformation of selected mature cork oak (Quercus suber L.). Plant Cell Rep 23:218-223

Alvarez R, Ordás RJ (2007) Improved genetic transformation protocol for cork oak (Quercus suber L.). Plant Cell Tissue Organ Cult 91:45-52

Alvarez R, AlvarezJM, Humara JM, Revilla A, Ordás RJ (2009) Genetic transformation of cork oak (Quercus suber L.) for herbicide resistance. Biotechnol Lett 31:1477-1483

Andrade GM, Merkle SA (2005) Enhancement of American chestnut somatic seedling production. Plant Cell Rep 24: 326-334

Anten NPR, Casado-García R, Pierik R, Ponds TL (2006) Ethylene sensitivity affects changes in growth patterns, but not stem properties, in response to mechanical stress in tobacco. Physiol Plant 128:274-282

Aronen T, Krajnakova J, Häggman H, Ryynanen L (1999) Genetic fidelity of cryopreserved embryogenic cultures of open-pollinated Abies cephalonica. Plant Sci 142:163-172

Ballester A, Sánchez MC, San-José MC, Vieitez FJ, Vieitez AM (1990) Development of rejuvenation methods for in vitro establishment, multiplication and rooting of mature trees. In: Rodríguez R, Tamés RS, Durzan DJ (eds) Plant Aging: Basic and Applied Approaches. Plenum Press, New York, pp 43-49

Ballester A, Vidal N, Vieitez AM (2009) Developmental stages during in vitro rooting of hardwood trees from material with juvenile and mature characteristics. In Niemii K, Scagel C (eds) Adeventitious Root Formation of Forest Trees and Horticultural Plants - From Genes to Applications. Research Singpost, Kerala, India, pp 277-299

Barreneche T, Casasoli M, Russell K, Akkak A, Meddour H, Plomion C, Villani F, Kremer A (2004) Comparative mapping between Quercus and Castanea using simple-sequence repeats (SSRs). Theor Appl Genet 108:558-566

Ben Amar A, Cobanov P, Boonrod K, Krezal G, Bouzid S, Ghorbel A, Reustle GM (2007) Efficient procedure for grapevine embryogenic suspension establishment and plant regeneration: role of conditioned medium for cell proliferation. Plant Cell Rep.26:1439-1447

Bergot M, Cloppet E, Pérarnaud V, Déqué M, Marçais B, Desprez-Loustau ML (2004) Simulation of potential range expansion of oak disease caused by Phytophthora cinnamomi under climate change. Global Change Biol 10:1539-1552

Berjak P, Walker M, Mycock DJ, Wesley-Smith J, Watt P, Pammenter NW (2000) Cryopreservation of recalcitrant zygotic embryos. In: Engelman F, Tajagi $\mathrm{H}$ (eds) Cryopreservation of Tropical Plant Germplasm. Current research progress and application. IPGRI, Rome, pp 140-155

Bonga JM, MacDonald JE, von Aderkas P (2008) Cloning conifers, with emphasis on mature trees. In: Rao GP, Zhao Y, Radchuck VV, Batnagar SK (eds) Advances in Plant Biotechnology. Studium Press LLC, Houston, USA, pp 475-490

Bonga JM, Klimazewska KK, von Aderkas P (2010) Recalcitrance in clonal propagation, in particular in conifers. Plant Cell Tissue Organ Cult 100:241-254

Bradford KJ, Van Deynze N, Parrott W, Strauss SH (2005) Regulating transgenic crops sensibly: lessons from plant breeding, biotechnology and genomics. Nature Biotech 23:439444 
Brendel O, Le Thiec D, Scotti-Saintagne C, Bodénès C, Kremer A, Guehl JM (2008) Quantitative trait loci controlling water use efficiency and related traits in Quercus robur L. Tree Gen. Genom 4:263-278

Brown LB, Allen-Diaz B (2009) Forest stand dynamics and sudden oak death: Mortality in mixed-evergreen forests dominated by coast live oak. Forest Ecol Manag 257:1271-1280

Brunner AM, Li J, DiFazio S, Shevchenko O, Montgomery BE, Mohamed R, Wei H, Ma C, Elias AA, VanWormer K, Strauss SH (2007) Genetic containment of forest plantations. Tree Gen Genom 3:75-100

Bueno MA, Gómez A, Boscaiu M, Manzanera JA, Vicente O (1997) Stress-induced formation of haploid plants through anther culture in cork oak (Quercus suber). Physiol Plant 99:335341

Bueno MA, Gómez A, Sepúlveda F, Segui JM, Testillano PS, Manzanera JA, Risueño MC (2003) Microspore-derived embryos from Quercus suber anthers mimic zygotic embryos and maintain haploidy in long-term anther culture. J Plant Physiol 160:953-960

Burley J, Kanowski PJ (2005) Breeding strategies for temperate hardwoods. Forestry 78:199208.

Canhoto JM, Lopes ML, Cruz GS (1999) Somatic embryogenesis and plant regeneration in myrtle (Myrtaceae). Plant Cell Tissue Organ Cult 57:13-21

Carraway DT, Merkle SA (1997) Plantlet regeneration from somatic embryos of American chestnut. Can J For Res 27:1805-1812

Casasoli M, Derory J, Morera-Dutrey C, Brendel O, Porth I, Guehl JM, Villani F, Kremer A (2006) Comparison of quantitative trait loci for adaptive traits between oak and chestnut based on expressed sequence tag consensus map. Genetics 172:533-546

Catry FX, Moreira F, Duarte I, Acácio V (2009) Factors affecting post-fire crown regeneration in cork oak (Quercus suber L.) trees. Eur J Forest Res 128:231-240

Celestino C, Hernández I, López-Vela D, Carneros E, Alegre J, Toribio M, Fernández-Guijarro B, Cardo L (2007) First data from a field trial of Quercus suber plants regenerated from mature selected trees and from their half-sib progenies by somatic embryogenesis. Acta Hort 748:215-218

Chalupa V (1993) Vegetative propagation of oak (Quercus robur and Q. petraea) by cutting and tissue culture. Ann Sci For 50, Suppl 1: 295-307

Chalupa V (1988) Large scale micropropagation of Quercus robur L. using adenine-type cytokinins and thidiazuron to stimulate shoot proliferation. Biol Plant 30:414-421

Chalupa V (1995) Somatic embryogenesis in oak (Quercus spp). In: Jain S, Gupta P, Newton R (eds) Somatic embryogenesis in woody plants, Vol. 2, Angiosperms. Kluwer, Dordrecht, The Netherlands, pp 67-87

Chalupa V (2000) In vitro propagation of mature trees of pedunculate oak (Quercus robur L.). J For Sci 46:537-542

Coggeshall MV (1996) Oak grafting techniques. Comb Procc Int Plant Prop Soc 46:481-486

Compton ME, Gray DJ (1996) Effects of sucrose and methylglyoxal bis-(guanylhydrazone) on controlling grape somatic embryogenesis. Vitis 35:1-6

Conte L, Cotti C, Cristofolini G (2007) Molecular evidence for hybrid origin of Quercus crenata Lam. (Fagaceae) from Q. cerris L. and Q. suber L. Plant Biosystems 141:181-193

Corredoira E, Ballester A, Vieitez AM (2003) Proliferation, maturation and germination of Castanea sativa Mill. somatic embryos originated from leaf explants. Ann Bot 92:11291136 
Corredoira E, Ballester A, Vieitez AM (2006a) Somatic embryogenesis in chestnut. In: Mujib S, Samaj J (eds) Somatic Embryogenesis, Plant Cell Monographs (2). Springer-Verlag, Heidelberg, pp 177-199

Corredoira E, Valladares S, Vieitez AM (2006b) Morphohistological analysis of the origin and development of somatic embryos from leaves of mature Quercus robur. In Vitro Cell Dev Biol Plant 42:525-533

Covelo G, Ferro E, Vielba J, Sánchez C (2009). Molecular analysis of adventitious rooting in Fagaceae species. In: Niemi K, Scagel C (eds) Adeventitious Root Formation of Forest Trees and Horticultural Plants - From Genes to Applications. Research Signpost, Kerala, India, pp 105-122

Cuenca B, San-José MC, Martínez MT, Ballester A, Vieitez (1999) Somatic embryogenesis from stem and leaf explant of Quercus robur L. Plant Cell Rep 18:538-543

Deng MD, Cornu D (1992) Maturation and germination of walnut somatic embryos. Plant Cell Tissue Organ Cult 28:195-202

Deroy J, Léger P, Garcia V, Schaeffer J, Hauser MT, Salin F, Lusching C, Plomion C, Glössl J, Kremer A (2006). Transcriptome analysis of bud burst in sessile oak (Quercus petraea). New Phytol 170:723-738

DeVerno LL, Charest PJ, Bonen L (1994) Somaclonal variation in somatic embryogenic cultures of Larix. Theor Appl Genet 88:727-732

Dodeman VL, Ducreux G, Kreis M (1997) Zygotic embryogenesis versus somatic embryogenesis. J Exp Bot 48:1493-1509

Ducousso A, Bordacs S (2004) EUFORGEN Technical Guidelines for genetic conservation and use for pedunculate and sessile oaks (Quercus robur and Q. petraea). International Plant Genetic Resources Institute, Rome, Italy, 6 pages

El Maâtaoui M, Espagnac H, Michaux-Ferrière N (1990) Histology of callogenesis and somatic embryogenesis induced in stem fragments of cork oak (Quercus suber) cultured in vitro. Ann Bot 66:183-190

Endemann M, Hristoforoglu K, Stauber T, Wilhelm E (2001) Assessment of age-related polyploidy in Quercus robur L. somatic embryos and regenerated plants using DNA flow cytometry. Biol Plant 44:339-345

Evers P, Vermeer E, van Eeden S (1993) Rejuvenation of Quercus robur. Ann Sci For 50, Suppl 1:330-335

Favre JM, Juncker B (1987) In vitro growth of buds taken from seedlings and adult-plant material in Quercus robur L. Plant Cell Tissue Organ Cult 8:49-60

Fenning TM (2006). The use of genetic transformation procedures to study defence and disease resistance traits of trees. In: Fladung M, Ewald D (eds) Tree Transgenesis. Springer, Heidelberg, pp 201-234

Fenning TM, Gershenzon J (2002) Where will the wood come from? Plantation forests and the role of biotechnology. Trends Biotechnol 20:291-296

Féraud-Keller C, Espagnac H (1989) Conditions d'apparition d'une embryogénèse somatique sur des cals issus de la culture de tissus foliaires du chêne vert (Quercus ilex). Can J Bot 67:1066-1070

Fernández-Guijarro B, Celestino C, Toribio M (1995) Influence of external factors on secondary embryogenesis and germination in somatic embryos from leaves of Quercus suber L. Plant Cell Tissue Organ Cult 41:99-106

Flachowsky H, Hanke M-V, Peil A, Strauss SH, Fladung M (2009) A review on transgenic approaches to accelerate breeding of woody plants. Plant Breeding 128:217-226. 
Forestry Commission (2009) Pyhtophthora ramorum (www.forestry.gov.uk/pramorum).

Gallego FJ, Martínez I, Celestino C, Toribio M (1997) Testing somaclonal variation using RAPDs in Quercus suber L. somatic embryos. Int J Plant Sci 158:563-567

García-Martín G, González-Benito ME, Manzanera JA (2001) Quercus suber L. somatic embryo germination and plant conversion: Pretreatments and germination conditions. In Vitro Cell Dev Biol Plant 37:190-198

García-Martín G, Manzanera JA, González-Benito ME (2005) Effect of exogenous ABA on embryo maturation and quantification of endogenous levels of ABA and IAA in Quercus suber somatic embryos. Plant Cell Tissue Organ Cult 80:171-177.

Gartland KMA.,Oliver CD (2007) Growing trees: risks and rewards for society. Tree Gen Genom 3:169-172

Gil B, Pastoriza E, Ballester A, Sánchez C (2003) Isolation and characterization of a cDNA from Quercus robur differentially expressed in juvenile-like and mature shoots. Tree Physiol 23:633-640

Gómez A, López JA, Pintos B, Camafeita E, Bueno MA (2009) Proteomic analysis from haploid and diploid embryos of Quercus suber L. identifies qualitative and quantitative differential expression. Proteomics 9: 4355-4367

Gömöry D, Schmidtova J (2007) Extent of nuclear genome sharing among white oak species (Quercus L. subgen, Lepidobalanus (Endl.) Oerst) in Slowakia estimated by allozymes. Plant System Evol 266:253-264

González-Benito ME, Pérez-Ruiz C (1992) Cryopreservation of Quercus faginea embryonic axes. Cryobiology 29:685-690

González-Benito ME, García-Martín G, Manzanera JA (2002a) Shoot development in Quercus suber L. somatic embryos. In Vitro Cell Dev Biol Plant 38:477-480

González-Benito ME, Prieto RM, Herradon E, Martin C (2002b). Cryopreservation of Quercus suber and Quercus ilex embryonic axes: In vitro culture, desiccation and cooling factors. CryoLetters 23:283-290

Grattapaglia D, Plomion C, Kirst M, Sederoff RR (2009) Genomics of growth traits in forest trees. Current Opinion Plant Biol 12:148-156

Gresshoff PM, Doy CH (1972) Development and differentiation of haploid Lycopersicon esculentum. Planta 107:161-170

Häggman H, Niemi K, Timonen H, Ylioja T, Chiang V (2006) Environmental aspects of lignin modified trees. In: Fladung M, Ewald D (eds) Tree Transgenesis. Springer, Heidelberg, pp 105-117.

Häggman H, Rusanen M, Jokipii S (2008) Cryopreservation of in vitro tissues of deciduous trees. In: Reed B (ed) Plant Cryopreservation: A Practical Guide. Springer, NY, pp 365-386

Hajji M, Dreyer E, Maçais B (2009) Impact of Erysiphe alphitoides on transpiration and photosynthesis in Quercus robur leaves. Eur J Plant Pathol 125:63-72

Harvengt L, Meier-Dinkel A, Dumas E, Collin E (2004) Establishment of a cryopreserved gene bank of European elms. Can J For Res 34:43-55

Heinze B, Schmit J (1994) Clonal fidelity of Norway spruce somatic embryos by RAPD. In: Pardos A, Ahuja MR, Rosello RE (eds) Biotechnology of Trees. J Investigación Agraria Sistema y Recursos Forestales, INIA, Spain, pp 143-148

Hernández I, Celestino C, Martínez I, Manjón JL, Díez J, Fernández-Guijarro B, Toribio M (2001) Cloning mature cork oak (Quercus suber L.) trees by somatic embryogenesis. Melhoramento 37:50-57 
Hernández I, Celestino C, Toribio M (2003a) Vegetative propagation of Quercus suber L. by somatic embryogenesis. I. Factors affecting the induction in leaves from mature cork oak trees. Plant Cell Rep 21:759-764

Hernández I, Celestino C, Alegre J, Toribio M (2003b) Vegetative propagation of Quercus suber L. by somatic embryogenesis: II. Plant regeneration from selected cork oak trees. Plant Cell Rep 21:765-770

Hornero J, Martínez I, Celestino C, Gallego FJ, Torres V, Toribio M (2001) Early checking of genetic stability of cork oak somatic embryos by AFLP analysis. Int J Plant Sci 162:827-833

Juncker B, Favre JM (1989) Clonal effects in propagating oak trees via in vitro culture. Plant Cell Tissue Organ Cult 19:267-276

Jung T, Blaschke H, Osswald W (2000) Involvement of soilborne Phytophthora species in Central European oak decline and the effect of site factors on the disease. Plant Pathol 49:706-718

Kernode AR (1995) Regulatory mechanisms in the transition from seed development to germination: interaction between and the see environment. In: Kigel J, Galili G (eds) Seed Development and Germination. Marcel Dekker, Inc., New York, pp 273-332

Kim YW (2000) Somatic embryogenesis in Quercus acutissima. In: Jain SM, Gupta PK, Newton RJ (eds) Somatic Embryogenesis in Woody Plants, Vol. 6. Kluwer Academic Publishers, Dordrecht, pp 671-685

Kleinschmit J (1993) Interspecific variation of growth and adaptive traits in European oak species. Ann Sci For 50, Suppl 1: 166-185

Knapic S, Louzada JL, Leal S, Pereira H (2008) Within-tree and between-tree variation of wood density components in cork oak trees in two sites in Portugal. Forestry 81:465-473

Krahl-Urban J (1959) Die Eichen. Paul Parey Verlag, Hamburg, 288 p

Kremer A, Casasoli M, Barreneche T et al. (2007) Fagaceae Trees. In: Kole C (ed) Genome Mapping and Molecular Breeding in Plants, Vol 7, Forest Trees. Springer, Berlin pp 161187

Krüssmann G (1978) Hanbuch der Laubgehölze. Paul Parey Verlag, Berlin, 79-115

Letarte J, Simion E, Miner M, Kasha KJ (2006) Arabinogalatans and arabinogalactan-proteins induce embryogenesis in wheat (Triticum aestivum L.) microspore culture. Plant Cell Rep 24:691-698

Lloyd G, McCown B (1980) Comercially-feasible micropropagation of mountain laurel, Kalmia latifolia, by use of shoot-tip culture. Comb Proc Intern Plant Prop Soc 30:421-427

Lopes T, Pinto G, Loureiro J, Costa A, Santos C (2006) Determination of genetic stability in long-term somatic embryogenic cultures and derived plantlets of cork oak using microsatellite markers. Tree Physiol 26:1145-1152

Loureiro J, Pinto G, Lopes T, Dolezel J, Santos C (2005) Assessment of ploidy stability of the somatic embryogenesis process in Quercus suber L. using flow cytometry. Planta 221:815822

Mallón R, Covelo P, Vieitez AM (2011) Improving secondary embryogenesis in Quercus robur. Application of temporary immersion for mass propagation. Plant Cell Tissue Organ Cult (in press)

Manion PD, Lachance D (1992) Forest decline concepts. In: Manion PD, Lachance D (eds) Forest Decline Concepts. American Phytopathological Society, St. Paul, Minnesota, USA, pp 181-190 
Manzanera JA, Bueno MA, Pardos JA (1996) Quercus robur L. (pedunculate oak). In: Bajaj YPS (ed) Biotechnology in Agriculture and Forestry, Vol. 35, Trees IV. Springer, Berlin, pp 321-341

Marçais B, Bréda N (2006) Role of an opportunistic pathogen in the decline of stressed oak trees. J Ecol 94:1214-1223

Martínez MT, Ballester A, Vieitez AM (2003) Cryopreservation of embryogenic cultures of Quercus robur using desiccation and vitrification procedures. Cryobiology 46:182-189

Martínez MT, Corredoira E, Valladares S, Jorquera L, Vieitez AM (2008) Germination and conversion of somatic embryos derived from mature Quercus robur trees: the effects of cold storage and thidiazuron. Plant Cell Tissue Organ Cult 95:341-351

Mauri PV, Manzanera JA (2003) Induction, maturation and germination of holm oak (Quercus ilex L.) somatic embryos. Plant Cell Tissue Organ Cult 74:229-235.

Mauri PV, Manzanera JA (2004) Effect of abscisic acid and stratification on somatic embryo maturation and germination of holm oak (Quercus ilex L.). In Vitro Cell Dev Biol Plant 40:495-498

Maynard CA, Powell WA, Polin-McGuigan LD, Vieitez AM, Ballester A, Corredoira E, Merkle SA, Andrade GM (2008) Chestnut. In: Kole C, Hall TC (eds) Compendium of Transgenic Crop Plants: Transgenic Forest Tree Species. Blackwell Publishing, Chichester, UK, pp 169-192

McCown BH (2000) Recalcitrance of woody and herbaceous perennials plants: Dealing with genetic predeterminism. In Vitro Cell Dev Biol Plant 36:149-154

Meentemeyer RK, Rank NE, Shoemaker DA, Oneal CB, Wickland AC, Frangioso KM, Rizzo DM (2008) Impact of sudden oak death on tree mortality in the Big Sur ecoregion of California. Biol Invasions 10:1243-1255

Meier-Dinkel A, Becker B, Duckstein D (1993) Micropropagation and ex vitro rooting of several clones of late-flushing Quercus robur L. Ann Sci For 50, Suppl $1: 319-322$

Merkle SA, Nairn CJ (2005) Hardwood tree biotechnology. In Vitro Cell Dev Biol Plant 41:602-619

Murashige T, Skoog F (1962) A revised medium for rapid growth and bioassays with tobacco tissue culture. Physiol Plant 15:473-497

Neger FT, Münch E (1950) Die Laubhölzer. Sammlung Göschen de Gruyter, Berlin Bd 718, $160 \mathrm{p}$

Nehra NS, Becwar MR, Rottmann WH et al. (2005) Forest biotechnology: Innovative methods, emerging opportunities. In Vitro Cell Dev Biol Plant 41:701-717

Parelle J, Zapater M, Scotti-Saintagne C, Kremer A, Jolivet Y, Dreyer E, Brendel O (2007) Quantitative trait loci of tolerance to waterlogging in a European oak (Quercus robur L.): physiological relevance and temporal effects patterns. Plant Cell Environ 30:422-434

Petit RJ, Bodénès C, Ducousso A, Roussel G, Kremer A (2004) Hybridization as a mechanism of invasion in oaks. New Phytol 161:151-164

Percy REL, Livingston NJ, Moran JA, von Aderkas P (2001) Desiccation, cryopreservation and water relations parameters of white spruce (Picea glauca) and interior spruce (Picea glauca $x$ engelmannii complex) somatic embryos. Tree Physiol 21:1303-1310

Pijut PM, Woeste KE, Vengadesan G, Michler CH (2007) Technological advances in temperate hardwood tree improvement including breeding and molecular marker applications. In Vitro Cell Dev Biol Plant 43:283-303

Pinto G, Valentim H, Costa A, Castro S, Santos C (2002) Somatic embryogenesis in leaf callus from a mature Quercus suber L. tree. In Vitro Cell Dev Biol Plant 38:569-572 
Pinto G, Silva S, Park YS, Neves L, Araújo C, Santos C (2008) Factors influencing somatic embryogenesis induction in Eucalyptus globulus Labill.: basal medium and anti-browning agents. Plant Cell Tissue Organ Cult 95:79-88

Pintos B, Bueno MA, Cuenca B, Manzanera JA (2008) Synthetic seed production from encapsulated somatic embryos of cork oak (Quercus suber L.) and automated growth monitoring. Plant Cell Tissue Organ Cult 95:217-225

Pintos B, Manzanera JA, Bueno MA (2010) Oak somatic and gametic embryos maturation is affected by charcoal and specific aminoacids mixture. Ann For Sci 67. DOI: 10.1051/forest/2009098.

Porth I, Scotti-Saintagne C, Barreneche T, Kremer A, Burg K (2005) Linkage mapping of osmotic stress genes of oak. Tree Gen Genom 1:31-40

Prewein P, Wilhelm E (2003) Plant regeneration from encapsulated somatic embryos of pedunculate oak (Quercus robur L.) In Vitro Cell Dev Biol Plant 39: 613-617

Prewein C, Vagner M, Wilhelm E (2004) Changes in water status and proline and abscisic acid concentrations in developing somatic embryos on pedunculate oak (Quercus robur) during maturation and germination. Tree Physiol 24:1251-1257

Puddephat IJ, Alderson PG, Wright NA (1999) in vitro root induction in axillary microshoots of Quercus robur L. Ann Appl Biol 134:233-239

Puigdejarrols P, Fernández-Guijarro B, Toribio M, Molinas M (1996). Origin and early development of secondary embryos in Quercus suber L. Int J Plant Sci 157:674-684

Puigdejarrols P, Mir G, Molinas M (2001) Ultrastructure of early secondary embryogenesis by multicellular and unicellular pathways in cork oak (Quercus suber L.). Ann Bot 87:179-189

Reed BM (2008) Cryopreservation-Practical Considerations. In: Reed B (ed) Plant Cryopreservation: A Practical Guide. Springer, NY, pp 3-13

Repo T, Mononen K, Alvila L, Pakkanen TT, Hänninen H (2008) Cold acclimation of pedunculate oak (Quercus robur L.) at its northernmost distribution range. Environ Exp Bot 63:59-70

Robin C, Desprez-Loustau ML, Delatour C (1992) Factors influencing the enlargement of trunk cankers of Phytophthora cinnamomi in red oak. Can J Forest Res 22:367-374

Roest S, Brueren HGMJ, Evers PW, Vermeer E (1991) Agrobacterium-mediated transformation of oak (Quercus robur L.). Acta Hortic 289:259-260

Romano A, Noronha C, Martins-Louçao MA (1992) Influence of growth regulators on shoot proliferation in Quercus suber L. Ann Bot 70:531-536

Saintagne C, Bodénès C, Barreneche T, Pot D, Plomion C, Kremer A (2004) Distribution of genomic regions differentiating oak species assessed by QTL detection. Heredity 12:20-30

Sánchez MC (1991) Propagación in vitro de material adulto de castaño y roble. Desarrollo de métodos de rejuvenecimiento. Doctoral Thesis, University of Santiago de Compostela, Spain

Sánchez MC, San-José MC, Ballester A, Vieitez AM (1996) Requirements for in vitro rooting of Quercus robur and Q. rubra shoots derived from mature trees. Tree Physiol 16:673-680

Sánchez MC, Martínez MT, Valladares S, Ferro E, Vieitez AM (2003) Maturation and germination of oak somatic embryos originated from leaf and stem explants: RAPD markers for genetic analysis of regenerants. J Plant Physiol 160: 699-707

Sánchez MC, Martínez MT, Vidal N, San-José MC, Valladares S, Vieitez AM (2008) Preservation of Quercus robur germplasm by cryostorage of embryogenic cultures derived from mature trees and RAPD analysis of genetic stability. CryoLetters 29:493-504

Sánchez N, Manzanera JA, Pintos B, Bueno MA (2005) Agrobacterium-mediated transformation of cork oak (Quercus suber L.) somatic embryos. New Forest 29:169-176 
San-José MC, Ballester A, Vieitez AM (1988) Factors affecting in vitro propagation of Quercus robur L. Tree Physiol 4:281-290

San-José MC, Vieitez AM, Ballester A (1990) Clonal propagation of juvenile and adult trees of sessile oak by tissue culture. Silvae Genet 39:50-55

San-José MC, Corredoira E, Martínez MT, Vidal N, Valladares S, Mallón R, Vieitez AM (2010) Shoot apex explants for induction of somatic embryogenesis in mature Quercus robur trees. Plant Cell Rep 29:661-671

Savill PS, Fennessy J, Samuel CJA (2005) Approaches in Great Britain and Ireland to the genetic improvement of broadleaved trees. Forestry 78:163-173

Savill, P.S. and P.J. Kanowski. 1993. Tree improvement programs for European oaks: goals and strategies. Ann. Sci. For. 50, Suppl 1:368-383

Schenk RU, Hildebrandt AC (1972) Medium and techniques for induction of growth of monocotyledonous and dicotyledonous plant cell culture. Can J Bot 50:199-204

Schroeder H, Degen B (2008) Spatial genetic structure in populations of the green oak leaf roller, Tortrix viridiana L. (Lepidoptera, Tortricidae). Eur J Forest Res 127:447-453

Schwarz OJ, Schlarbaum SE (1993) Axillary bud proliferation of 2 North American oak species: Quercus alba and Quercus rubra. Ann Sci For 50 (Suppl1): 425-429

Scotti-Saintagne C, Meriette S, Porth I, Goicoechea T, Bodénès C, Burg K, Kremer A (2004a) Genome scanning for interspecific differentiation between two closely related species [Quercus robur L. and Q. petraea (Matt.) Liebl.]. Genetics 168:1615-1626

Scotti-Saintagne C, Bodénès C, Barreneche T, Bertocchi E, Plomion C, Kremer A (2004b) Detection of quantitative trait loci controlling bud burst and height growth in Quercus robur L. Theor Applied Gen 109:1648-1659

Scotti-Saintagne C, Bertocchi E, Barreneche T, Kremer A, Plomion C (2005) Quantitative trait loci mapping for vegetative propagation in pedunculate oak. Ann Forest Sci 62:369-374

Sederoff R (2007) Regulatory science in forest biotechnology. Tree Gen Genom 3:71-74

Steiner KC (1993) Genetic improvement of oaks in North America. Ann Sci For 50 (Suppl 1): 359-367

Strauss SH, Tan H, Boerjan W, Sedjo R (2009) Strangle at birth? Forest biotech and the convention on biology diversity. Nature Biotech 27:519-527

Sunderlikova V, Wilhelm E (2002) High accumulation of legumin and Lea-like mRNAs during maturation is associated with increased conversion frequency of somatic embryos from pedunculate oak (Quercus robur L.). Protoplasma 220:97-103

Sunderlikova V, Salaj J, Matusikova I, Wilhelm E (2009a) Isolation and characterization of an embryo-specific Em-like gene of pedunculate oak (Quercus robur L.) and its temporal and spatial expression patterns during somatic and zygotic embryo development. Tree Struct Funct 23:135-144

Sunderlikova V, Salaj J, Kopecky D, Salaj T, Wilhelm E (2009b) Dehydrin genes and their expression in recalcitrant oak (Quercus robur) embryos. Plant Cell Rep 28:1011-1021

Sutton B (2002) Commercial delivery of genetic improvement to conifer plantations using somatic embryogenesis. Ann Forest Sci 59:657-661

Thomas FM, Blank R, Hartmann G (2002) Abiotic and biotic factors and their interactions as causes of oak decline in central Europe. For Pathol 32:277-307

Toribio M, Fernández C, Celestino C, Martínez MT, San-José MC, Vieitez AM (2004) Somatic embryogenesis in mature Quercus robur trees. Plant Cell Tissue Organ Cult 76:283-287 
Toribio M, Celestino C, Molinas M (2005) Cork oak, Quercus suber L. In: Jain SM, Gupta PK (eds) Protocol for Somatic Embryogenesis in Woody Plants. Springer, Dordrecht, The Netherlands, pp 445-457

Tsvetkov I, Hausman J-F (2005) In vitro regeneration from alginate-encapsulated microcuttings of Quercus sp. Sci Hortic 103:503-507

Valladares S, Toribio M, Celestino C, Vieitez AM (2004) Cryopreservation of embryogenic cultures from mature Quercus suber trees using vitrification. CryoLetters 25:177-186

Valladares S, Sánchez C, Martínez MT, Ballester A, Vieitez AM (2006) Plant regeneration through somatic embryogenesis from tissues of mature oak trees: true-to-type conformity of plantlets by RAPD analysis. Plant Cell Rep 25:879-886

Vengadesan G, Pijut PM (2007) In vitro propagation of northern red oak (Quercus rubra L.). In Vitro Cell Dev Biol Plant 45:474-482

Vengadesan G, Pijut PM (2009) Somatic embryogenesis and plant regeneration of northern red oak (Quercus rubra L.). Plant Cell Tissue Organ Cult 97:141-149

Vettraino AM, Barzanti GP, Bianco MC, Ragazzi A, Capretti P, Paoletti E, Luisi N, Anselmi A, Vannini A (2002) Occurrence of Phytophthora species in oak stands in Italy and their association with declining oak trees. Forest Pathol 32:19-28

Vidal N, Vieitez AM, Fernández MR, Cuenca B, Ballester A (2010a) Establishment of cryopreserved gene banks of European chestnut and cork oak. Eur J For Res 129:635-643

Vidal N, Mallón R, Valladares S, Meijomín AM, Vieitez AM (2010b). Regeneration of transgenic plants by Agrobacterium-mediated transformation of somatic embryos of juvenile and mature Quercus robur. Plant Cell Rep 29:1411-1422

Vieitez AM, San-José MC, Vieitez E (1985) In vitro plantlet regeneration from juvenile and mature Quercus robur L. J Hort Sci 60:99-106

Vieitez AM, Pintos F, San-José MC, Ballester A (1993) In vitro shoot proliferation determined by explant orientation of juvenile and mature Quercus rubra L. Tree Physiol 12:107-117

Vieitez AM, Sánchez MC, Amo-Marco JB, Ballester A (1994) Forced flushing of branch segments as a method for obtaining reactive explants of mature Quercus robur trees for micropropagation. Plant Cell Tissue Organ Cult 37:287-295

Vieitez AM, Sánchez C, García-Nimo ML, Ballester A (2007) Protocol for micropropagation of Castanea sativa. In: Jain SM, Häggman H (eds) Protocols for Micropropagation of Woody Trees and Fruits. Springer, Heidelberg, pp 299-312

Vieitez AM, Corredoira E, Ballester A, Muñoz F, Durán J, Ibarra M (2009) In vitro regeneration of important North American oak species Quercus alba, Quercus bicolor and Quercus rubra. Plant Cell Tissue Organ Cult 98:135-145

von Arnold S, Sabala I, Bozhkov P, Dyachock J, Filonova L (2002). Developmental pathways of somatic embryogenesis. Plant Cell Tissue Organ Cult 69:233-249

Wargo PM, Houston DR, LaMadeleine LA (1983) Oak decline. Forest Insect and Disease Leaflet 165. U.S. Department of Agriculture Service.

Wilhelm E, Burg A, Berenyi M, Endemann M, Rodler R (1996) Plantlet regeneration via somatic embryogenesis and investigations on Agrobacterium tumefaciens mediated transformation of oak (Quercus robur). In: Ahuja MR, Boerjan W, Neale DB (eds) Somatic Cell Genetics and Molecular Genetics of Trees. Kluwer, Dordrecht, pp 119-124

Wilhelm E (2000) Somatic embryogenesis in oak (Quecus spp.) In Vitro Cell Dev Biol Plant 36:349-357

Wilhelm E, Hristoforoglu K, Fluch S, Burg K (2005) Detection of microsatellite instability during somatic embryogenesis of oak (Quercus robur L.). Plant Cell Rep 23:790-795 
Zegzouti R, Arnould M-F, Favre J-M (2001) Histological investigation of the multiplication step in secondary somatic embryogenesis of Quercus robur L. Ann For Sci 58:681-690

Zhao XY, Su YH, Cheng ZJ, Zhang XS (2008) Cell fate switch during in vitro plant organogenesis. J Int Plant Biol 50:816-824 
Table 1. Studies on micropropagation through axillary shoot proliferation in oak species of economic relevance

\begin{tabular}{|c|c|c|c|c|}
\hline Species & Explant source/origin & Medium & Growth response & Reference \\
\hline \multicolumn{5}{|l|}{ Q. robur } \\
\hline & $\begin{array}{l}\text { Embryonic axes and } \\
\text { shoot tips and nodal } \\
\text { explants from } \\
\text { seedlings and stump } \\
\text { sprouts }\end{array}$ & $\begin{array}{l}\mathrm{GD}, \mathrm{BA}(4.44-0.44)^{1} \\
\text { Dipping IBA }(1 \mathrm{~g} / \mathrm{L}) 2 \\
\text { min }\end{array}$ & $\begin{array}{l}\text { Shoot proliferation } \\
\text { Rooting }\end{array}$ & Vieitez et al., 1985 \\
\hline & $\begin{array}{l}\text { Shoot tips from } \\
\text { seedlings and grafts } \\
\text { from mature trees }\end{array}$ & $\begin{array}{l}\text { 1/2MS, BA (0.44) } \\
\text { IBA (4.9) } 8 \mathrm{~d}\end{array}$ & $\begin{array}{l}\text { Shoot proliferation } \\
\text { Rooting }\end{array}$ & $\begin{array}{l}\text { Favre and Juncker } \\
\text { 1987; Juncker and } \\
\text { Favre } 1989\end{array}$ \\
\hline & $\begin{array}{l}\text { Shoot cultures from } \\
\text { seedlings and stump } \\
\text { sprouts }\end{array}$ & $\begin{array}{l}\text { WPM, BA } \\
\text { or TDE } \\
\text { or TDZ } \\
0.0090)\end{array}$ & $\begin{array}{l}\text { Shoot proliferation } \\
\text { Rooting, } \\
\text { acclimatization }\end{array}$ & Chalupa 1988 \\
\hline & $\begin{array}{l}\text { Shoot cultures from } \\
\text { seedlings and } \\
\text { epicormic shoots from }\end{array}$ & GD, BA (0.88) & $\begin{array}{l}\text { Shoot proliferation; } \\
\text { recycling horizontal } \\
\text { shoots }\end{array}$ & $\begin{array}{l}\text { San-José et el. } \\
1988\end{array}$ \\
\hline & mature trees & $\begin{array}{l}\text { GD, BA }(0.08) \text { or } Z \\
(0.46)\end{array}$ & $\begin{array}{l}\text { Shoot elongation, } \\
\text { rooting }\end{array}$ & \\
\hline & Shoot tips, nodal & WPM, BA (2.66-0.88) & Shoot proliferation & Chalupa 1993 \\
\hline & $\begin{array}{l}\text { segments from } \\
\text { seedlings and stump } \\
\text { sprouts }\end{array}$ & WPM, IBA (0.98-4.90) & $\begin{array}{l}\text { Rooting, } \\
\text { acclimatization }\end{array}$ & \\
\hline & $\begin{array}{l}\text { Shoot tips from forced } \\
\text { epicormic shoots from }\end{array}$ & $\begin{array}{l}\text { WPM, BA (4.4-2.2), } \\
\text { AC (0.5\%) }\end{array}$ & $\begin{array}{l}\text { Shoot proliferation } \\
\text { Rooting }\end{array}$ & Evers et al. 1993 \\
\hline & Zygotic embryos & $\begin{array}{l}\text { Commercial rooting } \\
\text { powder }\end{array}$ & Ex vitro rooting & $\begin{array}{l}\text { Meier-Dinkel et al. } \\
1993\end{array}$ \\
\hline & $\begin{array}{l}\text { Shoot tips and nodal } \\
\text { segments from forced } \\
\text { epicormic shoots from }\end{array}$ & GD, BA (0.88) & $\begin{array}{l}\text { Shoot proliferation; } \\
\text { recycling horizontal } \\
\text { shoots }\end{array}$ & Vieitez et al. 1994 \\
\hline & mature trees & IBA (14.8) $7 d$ & Rooting & \\
\hline & $\begin{array}{l}\text { Shoot cultures from } \\
\text { forced epicormic } \\
\text { shoots from mature } \\
\text { trees }\end{array}$ & $\begin{array}{l}\text { 1/3GD, IBA (122.5) } 24 \\
h, A C(1 \%)\end{array}$ & Rooting & Sánchez et al. 1996 \\
\hline & $\begin{array}{l}\text { Shoot cultures from } \\
\text { seedlings }\end{array}$ & 1/2GD, IBA (4.90) $7 \mathrm{~d}$ & Rooting & $\begin{array}{l}\text { Puddephat et al. } \\
1999\end{array}$ \\
\hline \multicolumn{5}{|l|}{$\begin{array}{l}\text { Q. } \\
\text { petraea }\end{array}$} \\
\hline & $\begin{array}{l}\text { Shoot tips and nodal } \\
\text { segments from } \\
\text { seedlings and stump } \\
\text { sprouts }\end{array}$ & $\begin{array}{l}\text { GD BA }(0.88) \\
1 / 2 \mathrm{GD} \text {, dipping IBA } \\
(0.5 \mathrm{~g} / \mathrm{L}) 6 \mathrm{~min}\end{array}$ & $\begin{array}{l}\text { Shoot proliferation } \\
\text { Rooting }\end{array}$ & $\begin{array}{l}\text { San-José et al. } \\
1990\end{array}$ \\
\hline & $\begin{array}{l}\text { Shoot tips and nodal } \\
\text { segments from } \\
\text { seedlings and stump } \\
\text { sprouts }\end{array}$ & $\begin{array}{l}\text { WPM, BA }(2.66-0.88) \\
\text { WPM, IBA }(0.98-4.90)\end{array}$ & $\begin{array}{l}\text { Shoot proliferation } \\
\text { Rooting }\end{array}$ & Chalupa 1993 \\
\hline
\end{tabular}

Q. rubra 




Q. suber

Apical and axillary GD, WPM, BA (4.44- Shoot proliferation

Romano et al, 1992 buds, flushed shoots 2.22), IAA (0.57)

from stem cuttings of Dipping IBA $(0.5 \mathrm{~g} / \mathrm{L})$ Rooting mature trees $10 \mathrm{~s}$

Q. alba

Shoot tips and nodal segments from GD, BA (0.88-0.44), Z Shoot proliferation, Vieitez et al. 2009 (2.28) horizontal explants epicormic shoots from 7-y-old trees $\quad$ 1/2GD, IBA (122.5) 48 Rooting h, AC (0.4\%)

Q. Shoot tips and nodal bicolor segments from GD, BA (0.88-0.44), Z Shoot proliferation, Vieitez et al. 2009 (2.28) horizontal explants epicormic shoots from 7-y-old trees 1/2GD, IBA (122.5) 48 Rooting h, AC $(0.4 \%)$

${ }^{1}$ Quantities in brackets are expressed in $\mu \mathrm{M}$ unless otherwise stated Mineral media: GD: Gresshoff and Doy (1972); MS: Murashige and Skoog (1962); WPM: Woody Plant Medium (Lloyd and McCown 1980)

Supplements: AC: Activated charcoal; BA: 6-Benzylaminopurine; $\mathrm{GA}_{3}$ : Gibberellic acid; IAA: Indole-3acetic acid; IBA: 3-Indolebutyric acid; TDZ: Thidiazuron; Z: Zeatin 
Table 2. Summary of somatic embryogenesis studies of Quercus species, with special reference to those published from the year 2000.

\begin{tabular}{|c|c|c|c|c|}
\hline Species & Explant & Origin & $\begin{array}{l}\text { Growth response/ } \\
\text { Remarks }\end{array}$ & Reference \\
\hline \multicolumn{5}{|l|}{ Q. robur } \\
\hline & Leaves, internodes & $\mathrm{S}$ & $\begin{array}{l}\text { Somatic embryos, plantlet } \\
\text { development }\end{array}$ & Cuenca et al. 1999 \\
\hline & Leaf segments & MT & $\begin{array}{l}\text { Somatic embryos, plantlet } \\
\text { development }\end{array}$ & Chalupa 2000 \\
\hline & Embryogenic lines & ZE & $\begin{array}{l}\text { Secondary somatic embryos, } \\
\text { anatomical study }\end{array}$ & Zegzouti et al. 2001 \\
\hline & Embryogenic lines & ZE & $\begin{array}{l}\text { Maturation, germination, plantlet } \\
\text { development }\end{array}$ & $\begin{array}{l}\text { Sunderlikova and Wilhelm } 2002 \\
\text { Prewein et al. } 2004\end{array}$ \\
\hline & Embryogenic lines & $\mathrm{S}$ & $\begin{array}{l}\text { Maturation, germination, plantlet } \\
\text { development }\end{array}$ & Sánchez et al. 2003 \\
\hline & Leaves & $\mathrm{MT}$ & $\begin{array}{l}\text { Somatic embryos, plantlet } \\
\text { development }\end{array}$ & Toribio et al. 2004 \\
\hline & Leaves & MT & $\begin{array}{l}\text { Somatic embryos, plantlet } \\
\text { development }\end{array}$ & Valladares et al. 2006 \\
\hline & Leaves & MT & $\begin{array}{l}\text { Somatic embryo origin, anatomical } \\
\text { study }\end{array}$ & Corredoira et al. 2006a,b \\
\hline & Embryogenic lines & MT & $\begin{array}{l}\text { Secondary somatic embryos, } \\
\text { plantlet development }\end{array}$ & Sánchez et al. 2008 \\
\hline & Embryogenic lines & MT & $\begin{array}{l}\text { Maturation, germination, plantlet } \\
\text { development }\end{array}$ & Martínez et al. 2008 \\
\hline & Shoot tips and leaves & $\begin{array}{l}\text { Shoot cultures } \\
\text { from MT }\end{array}$ & Somatic embryos, anatomical study & San-José et al. 2010 \\
\hline & Embryogenic lines & MT & Secondary somatic embryos & Mallón et al. (in press) \\
\hline \multicolumn{5}{|l|}{ Q. suber } \\
\hline & Leaves & MT & $\begin{array}{l}\text { Somatic embryos, plantlet } \\
\text { development }\end{array}$ & Hernández et al. 2001 \\
\hline & Embryogenic lines & $\mathrm{S}$ & Maturation, germination & García-Martín et al. 2001 \\
\hline & Embryogenic lines & $\mathrm{S}$ & $\begin{array}{l}\text { Secondary somatic embryos, } \\
\text { anatomical study }\end{array}$ & Puigdejarrols et al., 1996, 2001 \\
\hline & Leaves & $\mathrm{MT}$ & Somatic embryos & Pinto et al., 2002 \\
\hline & Embryogenic lines & ZE & Germination & González-Benito et al. 2002a \\
\hline & Leaves & $\mathrm{MT}$ & Somatic embryos & Hernández et al. 2003a \\
\hline & Leaves & MT & $\begin{array}{l}\text { Secondary somatic embryos, } \\
\text { germination, plantlet development }\end{array}$ & Hernández et al. 2003b \\
\hline & Anthers & $\mathrm{MT}$ & Microspore-derived embryos & Bueno et al. 2003 \\
\hline & Embryogenic line & $\mathrm{S}$ & Somatic embryo maturation & García-Martín et al. 2005 \\
\hline & Leaves & MT & $\begin{array}{l}\text { Somatic embryos, maturation, } \\
\text { germination, plantlet development }\end{array}$ & Toribio et al. 2005 \\
\hline & Somatic seedlings & $\mathrm{MT}$ & Acclimatization, field tests & Celestino et al. 2007 \\
\hline & Embryogenic lines & $\mathrm{MT}$ & Maturation, plantlet development & Pintos et al. 2010 \\
\hline
\end{tabular}

Q. rubra

Immature cotyledons ZE Somatic embryos, maturation, plantlet development

Vengadesan and Pijut 2009

Q. ilex

Immature zygotic

embryos 
Embryogenic lines

ZE

Maturation, germination

Mauri and Manzanera 2004

$Q$.

accutisima

Immature, mature

ZE

Somatic embryos, maturation, germination
$\operatorname{Kim} 2000$

S, seedlings; MT, mature trees; ZE, zygotic embryos 